\title{
A indústria brasileira no período 2007-2014: perdas e ganhos num ambiente de baixo crescimento *
}

\author{
Flávio Benevett Fligenspan **
}

\begin{abstract}
Resumo
Este artigo exibe um panorama geral das transformações ocorridas na Indústria brasileira no período 2007-2014 e faz a análise de tais mudanças. A base de dados utilizada é a Pesquisa Industrial Anual - Empresa, do IBGE. No período investigado, verificou-se um avanço importante da Indústria extrativa na estrutura industrial brasileira, seja de acordo com as variáveis Valor da produção e Valor da transformação industrial, seja pelo Investimento. Destacou-se o crescimento da atividade de Extração de petróleo e gás natural, em função da exploração das novas reservas brasileiras em águas profundas. Algumas atividades da Indústria de transformação ligadas aos bens que atendem às necessidades da base da pirâmide social aproveitaram bem os estímulos da política econômica da época e também avançaram. O balanço entre a produtividade do trabalho em baixa e as despesas com pessoal em alta gerou uma queda quase generalizada na rentabilidade, o que ajuda a explicar o pequeno crescimento dos investimentos.
\end{abstract}

Palavras chave: Indústria; Produtividade; Despesas com pessoal; Rentabilidade; Investimento.

\section{Abstract \\ The Brazilian industry between 2007-2014: losses and gains in a low-growth environment}

This article presents an overview of the transformations that took place in the Brazilian industry from 2007 to 2014. The database used is the IBGE's Pesquisa Industrial Anual (Annual Industrial Research). In the period under investigation, there was a significant advance of the extractive industry in the Brazilian industrial structure. The growth of Oil and Natural Gas Extraction was highlighted, as a result of the exploration of new Brazilian reserves in pre-salt areas. Some manufacturing activities linked to goods that meet the needs of the base of the social pyramid took full advantage of the economic policy stimuli at the time. The balance between falling labor productivity and rising labor costs has led to an almost generalized drop in profitability, which helps to explain the small growth in investments.

Keywords: Industry; Productivity; Personnel expenses; Profitability; Investment. JEL L6.

\section{Introdução}

Durante o século XX, por muitas décadas o desenvolvimento industrial brasileiro se alicerçou num modelo de proteção e fechamento para o exterior. Tal modelo, com seus defeitos e virtudes, foi decisivo para sustentar um crescimento vigoroso da economia no período do pós II Guerra até os anos 1980, quando emergiu a crise do financiamento externo e a crise financeira do Estado (Belluzzo; Almeida, 2002). Como se sabe, a década de 1980 foi perdida no que se refere ao crescimento e sequer foi encaminhada qualquer

* Artigo recebido em 12 de abril de 2017 e aprovado em 6 de fevereiro de 2018

** Professor do Departamento de Economia e Relações Internacionais da Universidade Federal do Rio Grande do Sul (UFRGS), Porto Alegre, RS, Brasil. E-mail: fli@ufrgs.br. 
solução para os problemas da inflação e da dívida externa ${ }^{1}$. Os anos 1990 marcaram uma reversão: a abertura comercial e financeira e a estabilização da inflação, associada a um longo processo de valorização da moeda nacional e juros elevados, romperam com o padrão anterior de competição. As empresas brasileiras reagiram da forma possível, privilegiando em primeiro lugar estratégias de sobrevivência. Em muitos casos isto implicou grandes dispensas de pessoal, fechamento de unidades e diminuição de linhas de produção, quando não se chegou às soluções mais radicais: mudança da região de operação, fusões, absorção por empresas estrangeiras ou mesmo o encerramento das atividades (Castro, 2001).

Os resultados de tal adaptação ao novo padrão logo apareceram, com mudanças estruturais - ganhos e perdas de participação de diversas atividades - e variações significativas em variáveis como emprego, salários, produtividade, margens de lucro, custos e preços. Se os anos 1990 representaram o choque e, portanto, as alterações mais duras, os anos 2000 trouxeram seus próprios desafios. Agora, as empresas que resistiram às mudanças iniciais deveriam se defrontar com a continuidade de condições macroeconômicas desfavoráveis, como juros altos e câmbio apreciado. A alteração da política econômica do Real em 1999, com a introdução do sistema de metas de inflação, retirou o protagonismo do câmbio como variável principal no controle da inflação e alçou a taxa de juros a este papel. Contudo, os sucessivos governos, Fernando Henrique II, Lula e Dilma, nunca abriram mão de algum controle sobre a taxa de câmbio, fazendo uso da chamada "flutuação suja" do câmbio (Averbug e Giambiagi, 2000). Os juros, por sua vez, foram mantidos elevados na maior parte do período 2000-2014, a não ser em dois curtos períodos, em 2009, no Governo Lula II, e em 2012, no Governo Dilma. Em contraposição às agruras do mercado interno, diversas atividades foram beneficiadas por um ambiente externo de expansão, com um aquecido mercado internacional de commodities. E pelo menos até 2008 não houve nada parecido com as grandes crises externas que abalaram os primeiros anos do Plano Real ainda na década de 1990, como a crise mexicana (1994/1995), a do sudeste asiático (1997) e a da moratória russa (1998).

Este artigo exibe as transformações ocorridas na Indústria brasileira no período 2007-2014², tanto nos seus aspectos estruturais, como nas variáveis que expressam a forma como ela respondeu aos desafios da política econômica e da competição. Busca-se compreender a evolução da Indústria brasileira pela ótica das empresas que a compõem, sua produtividade, sua capacidade de agregação de valor, seus custos, seus investimentos e sua rentabilidade, isto é, as variáveis que determinaram sua capacidade de resistir e se adaptar aos desafios da competição, seja no mercado doméstico - com os produtos importados -, seja no mercado internacional, num contexto de taxa de câmbio valorizada, juros elevados e condições sistêmicas desfavoráveis ${ }^{3}$. Desta maneira, espera-se oferecer uma contribuição empírica ao debate sobre os rumos da Indústria brasileira num período de enormes dificuldades, ajudando a construir um arcabouço para melhor entender questões

(1) Belluzo e Almeida (2002) mostram como foi o "ajuste defensivo" ou "de proteção" da grande empresa brasileira neste período, com manutenção da rentabilidade, redução do endividamento e preservação patrimonial. Como será visto a seguir, sobretudo em relação à rentabilidade, há diferenças significativas com o que ocorreu no período estudado neste artigo

(2) As seções 2 e 3 deste trabalho utilizam dados anteriores a 2007 sempre que oportuno para ilustrar o argumento.

(3) $\mathrm{Na}$ lista das condições sistêmicas desfavoráveis pode-se incluir, entre outras, a infraestrutura, o sistema de financiamento de longo prazo, o sistema tributário, o sistema jurídico e o marco regulatório. 
de fundo do debate atual, como o ganho de participação da indústria extrativa, a reprimarização de sua estrutura produtiva, a reprimarização de sua pauta exportadora, o desadensamento de cadeias produtivas, a perda de rentabilidade e a perda de participação do setor no PIB (Bresser-Pereira, 2010; Bacha; Bolle, 2013; Calixtre; Biancarelli; Cintra, 2014; Fligenspan et al., 2015; Carneiro, 2017).

Dado que o objetivo do artigo é oferecer, essencialmente, uma contribuição empírica, não se propõe uma discussão teórica explícita e exaustiva dos diferentes determinantes da competitividade industrial - empresariais, estruturais e sistêmicos -, o que requereria um espaço que vai além da extensão deste texto. Contudo, essas dimensões da competitividade industrial permeiam toda discussão a seguir, a qual busca orientação nos fundamentos da Economia Industrial, historicamente construídos em contraposição à Teoria Microeconômica Neoclássica. Tendo como pano de fundo a questão da competitividade da Indústria brasileira, toma-se como referência os conceitos de competitividade como eficiência e de competitividade como desempenho. O primeiro refere-se à “... capacidade da empresa de converter insumos em produtos com o máximo de rendimento. [...] Assim, competitividade é um fenômeno ex-ante, isto é, reflete o grau de capacitação detido pelas firmas, que se traduz nas técnicas por elas praticadas" (Ferraz; Kupfer; Haguenauer, 1995, p. 2).

Já no conceito de competitividade como desempenho “... é a demanda no mercado que, ao arbitrar quais produtos de quais empresas serão adquiridos, estará definindo a posição competitiva das empresas, sancionando ou não as ações produtivas, comerciais e de marketing que as empresas tenham realizado. [Neste caso, ] competitividade é uma variável ex-post que sintetiza os fatores preço e não-preço..." (Ferraz; Kupfer; Haguenauer, 1995, p. 2). Desta forma, o desempenho obtido no mercado, expresso pelo market share, é resultado de múltiplas determinações, uma consequência natural das escolhas empresariais quanto a técnicas de produção, mas também quanto a aspectos gerenciais, financeiros e comerciais. As variáveis estudadas nas próximas seções deste artigo se enquadram no mesmo escopo teórico das escolhas de Coutinho e Ferraz (1995, Anexo I, Quadro 3, Indicadores de Eficiência) e de trabalhos posteriores sobre a Indústria brasileira, como Moreira (1999) e IEDI (2008), seguindo a noção de competitividade como eficiência e como desempenho.

O corte temporal escolhido se justifica em função da disponibilidade de informações da base de dados utilizada para a análise, a Pesquisa Industrial Anual Empresa (PIA), do IBGE, que teve alterações metodológicas em 2007, inclusive com a reclassificação das atividades. A partir de 2007 a PIA adotou a versão 2.0 da Classificação Nacional de Atividades Econômicas (CNAE), em substituição à classificação anterior, CNAE 1.0, adaptando a classificação às mudanças ocorridas na atividade industrial brasileira e sincronizando-a à versão 4 da Clasificación Industrial Internacional Uniforme de todas las Actividades Económicas - CIIU/ISIC. Esta alteração possibilitou um maior detalhamento das atividades industriais e a comparação das estatísticas brasileiras com as de outros países. Assim, a série que era homogênea desde 1996 sofreu uma quebra em 2007, mas a partir deste ano é possível novamente construir séries homogêneas de diversas variáveis para todas as atividades. O período de oito anos entre 2007 e 2014 também 
coincide com o segundo mandato de Lula e o primeiro de Dilma na Presidência e pode ser caracterizado, quase integralmente, como de adaptação à crise financeira internacional. Por vezes, de acordo com as características da variável estudada e o objetivo da análise, chegouse mesmo a dividir o período de oito anos em dois quadriênios.

Sempre que foi necessária uma análise que descontasse os efeitos da inflação, utilizou-se como deflator o IGP-DI da FGV. Assim, foi possível verificar que entre 2007 e 2014 o valor bruto da produção industrial brasileira (total) cresceu $16 \%$ em termos reais, sendo que a Indústria extrativa dobrou de tamanho (expansão de $106 \%$ no período) e a Indústria de transformação teve expansão de $14 \%$. No mesmo intervalo, o número total de trabalhadores da Indústria brasileira aumentou $22 \%$, correspondendo a 8,45 milhões na média do ano de 2014, distribuídos em 190 mil empresas. As despesas médias com pessoal (gasto total com pessoal/número de pessoas empregadas) foram de $\mathrm{R} \$ 48,7$ mil por ano em 2014.

Mantendo a divisão da Indústria brasileira em Indústria extrativa e Indústria de Transformação, optou-se por retirar da base de dados do trabalho atividades pouco representativas, de acordo com variáveis como valor da produção, valor da transformação industrial e emprego. Desta forma, restaram as duas atividades extrativas mais significativas (petróleo e gás e minerais metálicos) e dezoito atividades de transformação. O recorte de tamanho é o das empresas com cinco ou mais pessoas ocupadas. Com tais escolhas, construiu-se uma base de dados que corresponde a $96 \%$ do Valor bruto da produção industrial e 94\% do emprego da Indústria brasileira em 2014.

Além desta Introdução, o trabalho tem mais s seções em que se analisam, por ordem, as mudanças estruturais ocorridas no período - que atividades ganharam e que atividades perderam participação -, e a evolução do coeficiente de agregação de valor, da produtividade do trabalho, da despesa com pessoal, da rentabilidade e dos investimentos; segue-se a Conclusão.

\section{Mudanças estruturais}

A principal mudança estrutural observada na Indústria brasileira no período 20072014 foi o ganho de participação da Indústria extrativa em detrimento da Indústria de transformação ${ }^{4}$. Este movimento está retratado na Tabela 1, tanto pelas variações (em pontos percentuais) do Valor da produção (VP) ${ }^{5}$ quanto pelas do Valor da transformação industrial (VTI). Os ganhos de participação da Indústria extrativa, de 3,0\% para 5,2\% pelo

(4) Esta relação, entre o ganho de participação da Indústria extrativa e a perda da Indústria de transformação, será referida várias vezes ao longo do texto. É importante ter claro que tal contraposição se dá apenas ao nível da participação de cada uma delas no total da Indústria; não se considera, obviamente, que o crescimento absoluto de um grupo de atividades deva significar o sacrifício automático do outro. Conforme Almeida e Novais (2014, p. 202): “... não há oposição entre agricultura e indústria ou entre a economia industrial e a economia de commodities e muito menos a necessidade de o país optar por uma especialização pendente para um ou para o outro lado. O êxito simultâneo da indústria e dos demais setores é perfeitamente possível, claro, mantendo-se uma taxa de câmbio competitiva." Os autores realçam o cuidado especial que se deve ter com a entrada de dólares pelo mercado financeiro, dados o diferencial de juros interno e externo e as facilidades para se fazer arbitragem no Brasil.

(5) A variável utilizada neste trabalho é Valor bruto da produção industrial (VBPI), de acordo com a PIA, daqui para frente referida apenas como Valor da produção (VP). 
VP e de $4,1 \%$ para $8,7 \%$ pelo VTI, correspondem a variações expressivas, construídas pelo desempenho das suas duas principais atividades: Extração de petróleo e gás natural; e Extração de minerais metálicos.

Tabela 1

Estrutura da Indústria brasileira, por Valor da produção (VP) e por Valor da transformação industrial (VTI) - 2007 e 2014

\begin{tabular}{|c|c|c|c|c|c|c|}
\hline & \multicolumn{3}{|c|}{ Estrutura por VP } & \multicolumn{3}{|c|}{ Estrutura por VTI } \\
\hline & 2007 & 2014 & $\begin{array}{c}\text { Variação } \\
\text { em pp } \\
(1)\end{array}$ & 2007 & 2014 & $\begin{array}{c}\text { variação } \\
\text { em pp } \\
\text { (1) }\end{array}$ \\
\hline Total & 100,0 & 100,0 & & 100,0 & 100,0 & \\
\hline Indústrias extrativas & 3,0 & 5,2 & 2,3 & 4,1 & 8,7 & 4,6 \\
\hline Extração de petróleo e gás natural & 0,0 & 1,0 & 1,0 & 0,0 & 1,4 & 1,4 \\
\hline Extração de minerais metálicos & 2,3 & 3,0 & 0,7 & 3,0 & 5,5 & 2,5 \\
\hline Indústrias de transformação & 97,0 & 94,8 & $-2,2$ & 95,9 & 91,3 & $-4,6$ \\
\hline Fabricação de produtos alimentícios & 15,7 & 19,2 & 3,5 & 12,2 & 15,6 & 3,4 \\
\hline Fabricação de bebidas & 2,4 & 2,6 & 0,2 & 3,1 & 3,2 & 0,1 \\
\hline Fabricação de produtos têxteis & 2,0 & 1,6 & $-0,4$ & 1,8 & 1,5 & $-0,3$ \\
\hline Confecção de artigos do vestuário e acessórios & 1,7 & 2,0 & 0,3 & 1,9 & 2,4 & 0,5 \\
\hline $\begin{array}{l}\text { Prep. de couros e fab. artef. couro, artigos viagem e } \\
\text { calçados }\end{array}$ & 1,6 & 1,4 & $-0,2$ & 1,5 & 1,6 & 0,1 \\
\hline Fabricação de celulose, papel e produtos de papel & 3,3 & 2,7 & $-0,6$ & 3,7 & 2,9 & $-0,8$ \\
\hline $\begin{array}{l}\text { Fabricação de coque, deriv. do petróleo e de } \\
\text { biocombustíveis }\end{array}$ & 10,2 & 9,2 & $-1,0$ & 15,8 & 14,0 & $-1,8$ \\
\hline Fabricação de produtos químicos & 10,0 & 9,5 & $-0,5$ & 7,7 & 7,0 & $-0,7$ \\
\hline $\begin{array}{l}\text { Fabricação de produtos farmoquímicos e } \\
\text { farmacêuticos }\end{array}$ & 1,7 & 1,7 & $-0,0$ & 2,6 & 2,2 & $-0,4$ \\
\hline $\begin{array}{l}\text { Fabricação de produtos de borracha e de material } \\
\text { plástico }\end{array}$ & 3,7 & 3,8 & 0,1 & 3,4 & 3,6 & 0,2 \\
\hline Fabricação de produtos de minerais não-metálicos & 2,8 & 3,5 & 0,7 & 3,2 & 3,7 & 0,5 \\
\hline Metalurgia & 8,6 & 6,6 & $-2,0$ & 8,0 & 5,2 & $-2,8$ \\
\hline $\begin{array}{l}\text { Fabricação de prod. de metal, exceto máquinas e } \\
\text { equipamentos }\end{array}$ & 3,6 & 3,3 & $-0,3$ & 3,8 & 3,4 & $-0,4$ \\
\hline $\begin{array}{l}\text { Fabricação de equip. de informática, prod. } \\
\text { eletrônicos e ópticos }\end{array}$ & 3,6 & 3,3 & $-0,3$ & 2,8 & 2,3 & $-0,5$ \\
\hline $\begin{array}{l}\text { Fabricação de máquinas, aparelhos e materiais } \\
\text { elétricos }\end{array}$ & 3,0 & 2,7 & $-0,3$ & 2,7 & 2,6 & $-0,1$ \\
\hline Fabricação de máquinas e equipamentos & 4,8 & 4,8 & 0,0 & 4,5 & 4,5 & 0,0 \\
\hline $\begin{array}{l}\text { Fabricação de veículos automotores, reboques e } \\
\text { carrocerias }\end{array}$ & 11,4 & 9,6 & $-1,8$ & 9,5 & 7,6 & $-1,9$ \\
\hline Fabricação de móveis & 1,1 & 1,3 & 0,2 & 1,0 & 1,4 & 0,4 \\
\hline
\end{tabular}

Fonte: Elaboração própria com base nas PIAs 2007 e 2014 - IBGE.

(1) pontos percentuais.

Como se sabe, o Brasil é um grande produtor e exportador de petróleo bruto e de minério de ferro e estes dois produtos foram muito beneficiados pela expansão do comércio internacional - preços e quantidades em alta - no período analisado, sobretudo pelo acréscimo de demanda oriundo de países asiáticos, em especial da China. A crise financeira 
internacional, iniciada no final de 2008, interrompeu brevemente uma trajetória de alta de preços de commodities que vinha ocorrendo desde 2003, com uma redução de preços de $30 \%$ em 2009 frente a 2008, de acordo com o $\mathrm{FMI}^{6}$. A tendência de alta logo reapareceu a partir de 2010 e em 2011 os preços já estavam 12\% superiores aos de 2008. Seguiram-se três anos de suave queda (2012, 2013 e 2014), mas em 2014 os preços estavam 27\% maiores que os de 2007, praticamente iguais aos de 2008 e $164 \%$ superiores aos do momento inicial deste ciclo de alta, em $2003^{7}$.

A robusta expansão do mercado internacional de commodities foi, portanto, o motor da expansão da Indústria extrativa nacional, tanto no que se refere ao VP e ao VTI, como também em relação a outras variáveis observadas pelas PIAs para este setor: emprego, investimentos, receitas e gastos com pessoal. Efetivamente, os produtores brasileiros deram uma resposta rápida ao impulso que veio de fora, não só em relação à demanda presente, como também fazendo uma aposta no futuro, na continuidade deste ambiente de expansão, haja vista a concentração de investimentos nas atividades produtoras de commodities. E deve-se observar que este movimento de concentração em resposta aos estímulos internacionais não é novo, pois IEDI (2008) já o notara para o período entre 1996 e 2006, manifestando preocupação com a excessiva confiança da indústria brasileira na continuidade da expansão do mercado internacional e com a dependência cada vez maior que se estabelecia de tal performance ${ }^{8}$. Porém, não é só a questão da dependência que importa, mas também o fato de que tais atividades têm baixa capacidade de influenciar o crescimento via suas ligações para frente e para trás com outras atividades da matriz produtiva brasileira, conforme alertam Marconi, Rocha e Magacho (2016) ${ }^{9}$.

No interior da Indústria de transformação, algumas atividades classificadas como produtoras de bens de consumo deram respostas positivas; elas foram beneficiadas pela expansão do mercado de trabalho, tanto no que se refere ao aumento do emprego, quanto à elevação dos rendimentos médios, variável fortemente influenciada pela continuidade da política de recuperação do valor real do salário mínimo. Um dos casos mais marcantes é o de produtos alimentícios, que avançou 3,5 pontos percentuais na estrutura industrial entre 2007 e 2014 pelo VP, o que representou mais de $20 \%$ de aumento em relação ao peso que detinha no início do período (3,4 pontos percentuais pelo VTI). Na mesma linha também

(6) Conforme o índice de preços de todas as commodities, em IMF Data (2016).

(7) Se dividirmos o período de oito anos estudado neste trabalho em dois quadriênios, fica bem nítida a diferença em relação à evolução dos preços internacionais das commodities; conforme IMF Data (2016), no quadriênio 2007-2010 houve alta de $13 \%$ e no quadriênio 2011-2014 houve queda de 11\%. Para o período completo há alta de $27 \%$ porque entre 2010 e 2011 os preços subiram $26 \%$.

(8) O trabalho clássico sobre a competitividade da indústria brasileira (Coutinho; Ferraz, 1995, Introdução) já se preocupava com o mesmo tema, referindo-se a um período ainda anterior a 1996.

(9) Este trabalho chama atenção para o baixo encadeamento da atividade de extração de minério de ferro (para frente e para trás) e para o baixo coeficiente para trás da extração de petróleo e gás, diferentemente de seu coeficiente pra frente. O rápido ganho de participação da Indústria extrativa na estrutura industrial brasileira e o consequente aumento da dependência do bom desempenho do mercado internacional de commodities conduz ao importante debate sobre "maldição dos recursos naturais", "doença holandesa", reprimarização da estrutura industrial, reprimarização da pauta de exportações e desindustrialização. Apesar da sua importância, estes temas não são objeto deste artigo. Há farta bibliografia sobre estes temas e os interessados podem recorrer, entre outros, à bibliografia já referida na Introdução deste artigo e a Oreiro e Feijó (2010), Marconi e Rocha (2012), Veríssimo e Xavier (2014), Nassif et al. (2015), IEDI (2016) e Hiratuka e Sarti (2017). 
vale registrar o caso de artigos do vestuário, com ganhos de 0,3 e 0,5 pontos percentuais na estrutura industrial, respectivamente, de acordo com as variáveis VP e VTI no intervalo investigado.

As atividades de calçados e de equipamentos de informática e produtos eletrônicos, também produtoras de bens de consumo, não tiveram o mesmo desempenho positivo das listadas anteriormente; ao contrário, chegaram a sofrer perdas de participação na estrutura industrial. Ocorre que nestes casos os produtores nacionais sofreram a forte concorrência dos similares estrangeiros, que se beneficiaram de um processo de apreciação cambial com efeitos tanto no mercado interno como, para calçados, na capacidade de competir no mercado internacional ${ }^{10}$. No caso dos equipamentos de informática e produtos eletroeletrônicos, é necessário lembrar que muitas empresas que atuam no Brasil são filiais de grandes grupos estrangeiros e que, diante das dificuldades de produzirem no País, passaram cada vez mais a importar produtos prontos ou peças e componentes para apenas montar seus produtos nas plantas domésticas, num flagrante retrocesso histórico.

A atividade de veículos automotores, reboques e carrocerias constitui um caso especial; durante quase todo período ela teve percentuais elevados de participação na estrutura industrial, sobretudo pelo VP. Apenas no último ano, 2014, quando a Indústria brasileira já apresentou crescimento negativo e a atividade de veículos sofreu uma queda expressiva da produção física (17\%, segundo a Pesquisa Industrial Mensal do IBGE), houve perda de participação ${ }^{11}$. Ocorre que veículos são produtos de valor unitário elevado para a renda média do País e, portanto, dependem muito de todas as condições que cercam o crédito para serem vendidos, como expectativas positivas e confiança dos consumidores no futuro; e comprometimento da renda das famílias com o serviço de suas dívidas.

Desde o primeiro semestre de 2012 o Índice de Confiança do Consumidor, pesquisado pela Fundação Getulio Vargas, entrou numa trajetória de queda quase constante, só interrompida num pequeno intervalo de tempo, no segundo semestre de 2013; entre abril de 2012 e dezembro de 2014 o Índice caiu 23\%, na série com ajuste sazonal. Por sua vez, o Comprometimento de renda das famílias com pagamento do serviço da dívida com o Sistema Financeiro Nacional, que havia diminuído entre a metade do ano de $2012 \mathrm{e}$ a metade de 2013, voltou a crescer desde então, de acordo com o Banco Central do Brasil. Estas são duas variáveis que ajudam a explicar o recuo das vendas de bens de alto valor unitário, a despeito dos históricos incentivos governamentais para a compra de veículos, como a redução de IPI e programas como o Inovar Auto. Além disso, 2013 representa o ponto final de um grande ciclo de vendas de veículos que começou ainda na metade da década de 2000. Nos anos de 2007 a 2010 as taxas anuais de crescimento das vendas do item Veículos, motocicletas e peças, da Pesquisa Mensal do Comércio (IBGE), foram sempre superiores a 10\%, fazendo com que, naturalmente, fosse se aproximando um ponto

(10) O processo de apreciação da moeda nacional vem de longa data, mesmo antes do início do Plano Real. Observese que, segundo o índice da taxa de câmbio efetiva real (cesta de 13 moedas - deflator IPA), produzido pela Funcex, de 1992 a 2014 a apreciação foi de 47\%. No período estudado neste artigo, entre 2007 e 2014, a apreciação foi de 8\%. Evidentemente, o câmbio impacta de forma diferente as diversas atividades industriais, mas é possível dizer que importantes cadeias produtivas brasileiras de bens intermediários e bens de capital sentiram os efeitos negativos do processo de apreciação.

(11) Pelo VP, a participação de veículos girou entre 11\% e 12\% para o período 2007 a 2013 e teve uma queda abrupta para 9,6\% em 2014. Pelo VTI a queda já vinha ocorrendo desde 2012. 
limite da expansão do consumo destes bens. Em 2011 e 2012 ainda ocorreram taxas entre $6 \%$ e $7 \%$, mas em 2013 a taxa foi de apenas $1,5 \%$ e em 2014 a queda foi pronunciada, $9,4 \%$.

Uma atividade que teve ganhos de participação na estrutura industrial brasileira passíveis de serem explicados por políticas públicas foi a de minerais não-metálicos. Desde o primeiro mandato de Lula, foram várias as ações no sentido de fomentar a Construção civil - indústria que usa insumos produzidos pela atividade de minerais não-metálicos, como cimento e cerâmicas -, desde o expressivo aumento do volume de crédito $^{12}$, a redução do IPI de materiais de construção, até as alterações institucionais, como o novo regramento sobre a recuperação do imóvel pelo agente financiador ou pela própria construtora nos casos de inadimplência. A regra anterior era muito leniente com os inadimplentes, tornando difícil a efetiva cobrança de prestações atrasadas. A mudança proporcionou um sistema semelhante ao da alienação fiduciária, generalizadamente utilizado no financiamento de automóveis, que permite a rápida retomada do bem pelo agente financiador nos casos de não pagamento das prestações.

A instituição do Programa Minha Casa Minha Vida (MCMV), em 2009, também representou um marco para a Indústria da Construção civil e para a atividade de minerais não-metálicos. Através do financiamento subsidiado de moradias populares em larga escala, se propiciou acesso às famílias de baixa renda ao imóvel próprio e, ao mesmo tempo, se estimulou o emprego e a produção na cadeia da Construção. Associado ao MCMV, foram lançados dois outros programas, o Programa Nacional de Habitação Urbana e o Programa Nacional de Habitação Rural, que avançaram em relação ao financiamento do imóvel novo, oferecendo também a possibilidade de uso de recursos para reformas em imóveis já existentes. Assim foi possível ampliar o consumo de materiais de construção.

Além dos Programas com apoio estatal, a recuperação do poder de compra das camadas de mais baixa renda, que teve sustentação num mercado de trabalho mais pujante e com maior fiscalização do Ministério do Trabalho e Emprego (MTE) ${ }^{13}$, fortaleceu o conhecido "consumo formiga", isto é, a demanda de materiais de construção em quantidades pequenas, feita diretamente pelas famílias para a realização de reformas e ampliações nos próprios imóveis.

Também associado ao MCMV, surgiu em 2013 o Programa Minha Casa Minha Vida Melhor, que financiava através da Caixa Econômica Federal a compra de móveis e eletrodomésticos para os participantes adimplentes do MCMV com juros de 5\% ao ano. Os produtos e seus preços eram pré-definidos no Programa num valor máximo total de $\mathrm{R} \$ 5$ mil e prazo de pagamento de 48 meses. Tais condições, bastante favoráveis, ajudaram a

(12) Segundo o Banco Central do Brasil, o saldo das operações de crédito ao setor imobiliário passou de 1,62\% do PIB em março de 2007 para 8,75\% em dezembro de 2014. Conforme Araujo et al. (2016), o saldo das operações de crédito imobiliário teve crescimento real de $591 \%$ entre dezembro de 2007 e dezembro de 2014 . Além disso, a taxa de juros caiu e os prazos de financiamento aumentaram no período.

(13) A maior fiscalização do MTE forçou a formalização - registro em carteira - de muitos trabalhadores antes informais. A consequência disso, além da elevação dos rendimentos e do pagamento de férias, $13^{\circ}$ salário etc, foi a possibilidade de estes trabalhadores terem maior acesso ao consumo via crédito que antes lhes era negado por não oferecerem comprovação de renda. 
estimular a produção destas atividades, em especial a de móveis, mais uma que teve desempenho positivo no período estudado, beneficiada pelo Programa e também pelas condições positivas propiciadas pelo mercado de trabalho. Seus pequenos aumentos em pontos percentuais na estrutura industrial, 0,2 e 0,4, respectivamente, pelo VP e pelo VTI, representam variações percentuais significativas em relação ao peso do início do período para estas duas variáveis.

Ainda deve-se destacar que três outras atividades com presença significativa na estrutura industrial brasileira tiveram quedas não desprezíveis de participação entre $2007 \mathrm{e}$ 2014. São elas os derivados do petróleo e de biocombustíveis, os produtos químicos e a metalurgia - esta com perdas mais expressivas, de 2,0 pontos percentuais pelo VP e 2,8 pontos percentuais pelo VTI -. Além da perda quantitativa na estrutura industrial, é importante atentar-se para o aspecto qualitativo envolvido, visto que estas atividades representam elos intermediários de diversas cadeias produtivas, o que remete ao debate sobre desadensamento e perda de importância dos segmentos de maior intensidade tecnológica (Carneiro, 2017).

Por fim, no que se refere ao tema da concentração - aqui entendida como o somatório das participações das quatro principais atividades no total do VP e do VTI da Indústria brasileira (CR4) -, não foi possível identificar um nítido movimento de mudança no período de oito anos. As quatro atividades com maior presença na distribuição do VP detinham 47,3\% do VP total da Indústria em 2007 e, 47,5\% em 2014, sem modificações na composição do grupo: Fabricação de produtos alimentícios, Fabricação de veículos automotores, reboques e carrocerias, Fabricação de coque, derivados do petróleo e de biocombustíveis e Fabricação de produtos químicos.

A mesma observação feita através da variável VTI mostra uma suave desconcentração de um ponto percentual, sem que se possa entendê-la imediatamente como tendência: de 45,5\% em 2007 para 44,2\% em 2014. Contudo, nota-se que de 2007 a 2014 houve uma mudança na composição do grupo, que tinha no início do período, por ordem, Fabricação de coque, derivados do petróleo e de biocombustíveis, Fabricação de produtos alimentícios, Fabricação de veículos automotores, reboques e carrocerias e Metalurgia. Em 2014, o último lugar do grupo passou a ser ocupado por Fabricação de produtos químicos, dado que a perda da Metalurgia foi muito grande no intervalo pesquisado (2,8 pontos percentuais).

\section{Coeficiente de agregação de valor}

O quociente VTI/VP expressa um coeficiente de agregação de valor. O VTI é tido como uma proxy do valor adicionado, portanto, ao se obter a participação do VTI no VP, observa-se a proporção do valor adicionado no valor da produção, isto é, quanto se está adicionando de valor ao longo do processo produtivo. É claro que uma atividade industrial ou mesmo a indústria como um todo - total das atividades industriais - é tanto mais importante para a economia de uma região ou país quanto maior seu coeficiente de agregação de valor. Um coeficiente elevado normalmente é gerado por atividades mais complexas, mais intensivas em tecnologia e que empregam trabalhadores mais qualificados e com maior remuneração. Por outro lado, atividades que se resumem à mera montagem de 
produtos, por exemplo, agregam pouco valor às peças e componentes considerados como consumo intermediário. Normalmente, empregam trabalhadores com baixo nível de qualificação e que ganham os menores salários.

Ainda que se tenham em conta estas características gerais do coeficiente de agregação de valor, a observação de seu aumento ou diminuição para determinada região em um período específico do tempo não pode ser descolada de seu contexto histórico. A conhecida proteção da indústria brasileira, que se desenvolveu à luz do modelo de substituição de importações, logrou êxito em relação ao seu principal objetivo, a expansão, a diversificação e o fortalecimento das atividades industriais, mas trouxe uma série de vícios já bem estudados pela literatura ${ }^{14}$.

A expectativa da grande maioria dos pesquisadores diante do processo de abertura comercial e reestruturação industrial verificado no Brasil a partir do início dos anos 1990 era de que o incremento gradual das importações de matérias primas, bens de capital e mesmo bens de consumo, levasse à redução de um dos maiores vieses do modelo, a elevada verticalização, muitas vezes associada à exigência de índices de nacionalização ao longo das cadeias produtivas (Moreira, 1999; Castro, 2001) ${ }^{15}$. Assim, a importação de matérias primas, deslocando parte da demanda doméstica para os produtos fabricados no exterior, deveria reduzir a agregação de valor doméstica e, portanto, diminuir a relação VTI/VP ${ }^{16}$. Naquele momento, a redução do coeficiente não era interpretada automaticamente como algo ruim ou um mau sinal para a indústria nacional; pelo contrário, desde que o processo fosse gradual e de intensidade moderada, seria um sinal de oxigenação e modernização necessárias, trazidas pela abertura comercial depois de décadas de um fechamento que ajudou a construir a indústria nacional, mas que também a moldou com níveis altos de ineficiência técnica.

Conforme Moreira (1999), tal expectativa de redução do coeficiente VTI/VP para a indústria de transformação brasileira não se concretizou logo nos primeiros anos da década de 1990, mas somente a partir do Plano Real, quando a inflação bem mais baixa trouxe a recuperação do poder de compra e permitiu a efetiva comparação de preços entre produtos nacionais e estrangeiros ${ }^{17}$. Castro (2001), sem se referir diretamente ao coeficiente VTI/VP, corrobora a visão de que o Plano representou um divisor de águas para a indústria brasileira; ele divide os anos 1990 em dois subperíodos, o primeiro de 1990 a 1994, que ele chama de "cirurgia e reorganização", e o segundo, a partir do Plano Real, chamado de "catch up produtivo". De acordo com o autor, nos primeiros anos daquela

(14) Um trabalho clássico sobre o tema é Tavares (1978). Há bibliografia mais recente sobre a questão: Moreira (1999) é um exemplo, sintetizando os aspectos negativos do modelo de substituição de importações.

(15) Para uma análise do caso específico da indústria automobilística brasileira, nos momentos iniciais do processo de desverticalização nos anos 1990, ver Amato Neto (1994).

(16) A terceirização de atividades meio, tais como alimentação, segurança e limpeza, característica desta época, também ajudou a reduzir a relação VTI/VP na medida em que retirou empregados antes registrados nas diversas atividades industriais e os recolocou em empresas prestadoras de serviços, com o objetivo de reduzir custos. Na hipótese da manutenção da produção final, esta ação diminuiu o VTI das empresas da indústria, mas manteve o VP; no entanto, esta redução do coeficiente de agregação de valor pode ser considerada um viés da medida, já que ela não se deu por mudanças no cerne do processo produtivo nem reflete a substituição de insumos nacionais por importados.

(17) Conforme o autor (Moreira, 1999, p. 315), o coeficiente chegou a subir entre 1989 e 1993 e caiu em 1994 e 1995. 
década a inflação elevada não permitiu que todos os efeitos da abertura se manifestassem, como por exemplo, a entrada de matérias primas e bens de capital estrangeiros que seriam usados para elevar a qualidade e a competitividade da produção nacional. A partir de 1994 o ajuste estrutural da indústria brasileira ocorreu de forma mais ampla, com a importação de matérias-primas e equipamentos, não se restringindo apenas a mudanças do "chão de fábrica" e demissões, características marcantes do subperíodo "cirurgia e reorganização". Também é certo que o câmbio valorizado e as reduções de alíquota do imposto de importação, peças chave do Plano, tiveram um papel importante desde a introdução do Real.

Assim, a esperada redução do coeficiente só apareceu realmente a partir de 1994. O Gráfico 1, com informações das Pesquisas Industriais Anuais (PIAs) para a Indústria de transformação brasileira, apresenta duas curvas, uma para o período 1996-2007 e outra para o período 2007-2014; isto em função da mudança metodológica na série das PIAs justamente em 2007, o que tornou a série não homogênea ${ }^{18}$. O Gráfico mostra um processo de redução de cinco pontos percentuais da relação VTI/VP entre 1996 e 2004, o que atende à expectativa dos pesquisadores diante da combinação dos processos de abertura comercial, apreciação cambial e redução de alíquotas de importação nos primeiros anos do Real. Segue-se uma elevação por dois anos, 2005 e 2006, e uma nova queda em 2007. É possível considerar que este período de doze anos (1996-2007) consolidou os ajustes esperados desde o início da década de 1990.

Gráfico 1

Relação VTI/VP para a Indústria de transformação brasileira, em \% - 1996-2014

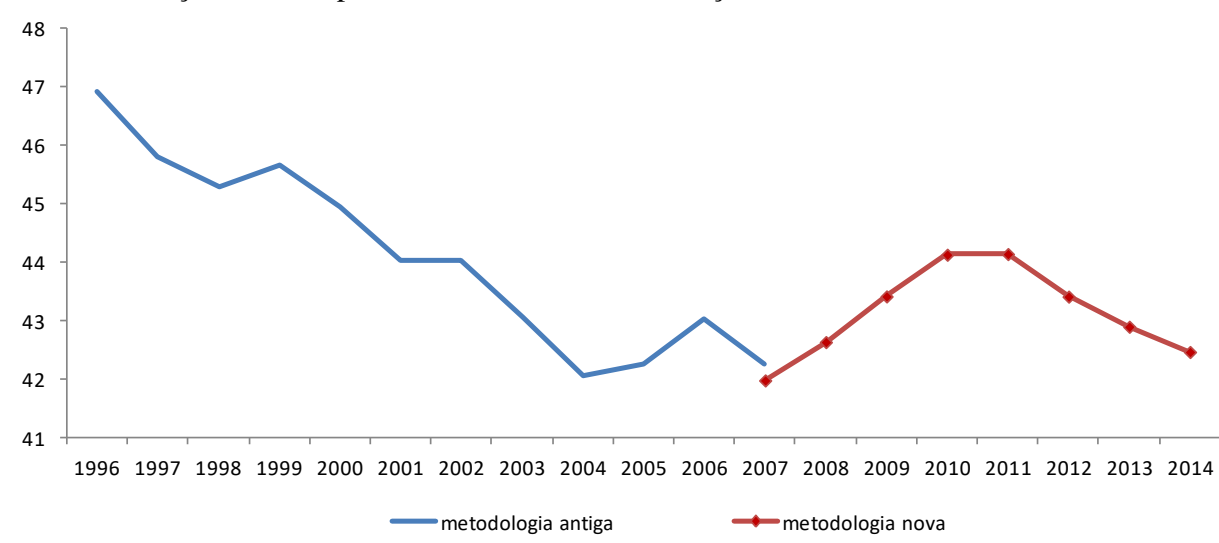

Fonte: Elaboração própria com base nas PIAs - IBGE.

A curva correspondente às informações com a nova metodologia das PIAs, para o período 2007-2014, mostra um movimento de ascensão do coeficiente até o biênio 20102011, de dois pontos percentuais, e a seguir um retorno ao nível de $42 \%{ }^{19}$. Diferentemente

(18) O Gráfico 1 traz as informações do período 1996-2007, não abarcado nos demais tópicos deste trabalho, justamente porque é nele que aparece nitidamente o esperado movimento de queda do coeficiente de agregação de valor.

(19) A relação VTI/VP para a Indústria extrativa passou de 58\% em 2007 para 73\% em 2014; tal elevação deve-se à atividade de Extração de minerais metálicos (57\% em 2007 e $79 \%$ em 2014), já que a atividade de Extração de petróleo e gás natural teve queda do coeficiente (66\% em 2007 e $61 \%$ em 2014). 
do período anterior (1996-2007), em que fica bem caracterizada a queda do coeficiente e é possível associá-la ao processo de abertura e à política econômica do Real, não há uma explicação evidente para o comportamento da variável a partir de 2007, nem ligada à taxa de câmbio e às tarifas de importação, nem ligada às oscilações dos custos de produção, dos mark-ups e dos preços.

O câmbio até sofreu uma elevação brusca no final de 2008, por conta do início da crise financeira, com a quebra do Banco Lehman Brothers nos Estados Unidos em setembro daquele ano. Mas já no início de 2009 retomou sua rota de apreciação do real, que permaneceu até a metade de 2011, já no primeiro ano do Governo Dilma; a partir daí houve uma recuperação da taxa de câmbio real. Como se vê, não é possível construir uma relação direta entre o movimento de alta, seguido de baixa, do coeficiente VTI/VP e da taxa de câmbio para este período ${ }^{20}$.

As atividades que tiveram os maiores aumentos do coeficiente VTI/VP no período 2007-2014 foram Extração de minerais metálicos (39\%), Fabricação de móveis (19\%), Preparação de couros e fabricação artefatos de couro, artigos para viagem e calçados (16\%), Confecção de artigos do vestuário e acessórios (15\%) e Fabricação de máquinas, aparelhos e materiais elétricos (10\%). Os destaques negativos ficaram por conta de Metalurgia (-13\%) e Fabricação de produtos farmoquímicos e farmacêuticos (-11\%). Observa-se, portanto, que não há um padrão definido para os melhores ou piores desempenhos, seja por intensidade de fator, categoria de uso ou qualquer outra classificação usualmente aplicada à Indústria.

\section{Produtividade do trabalho em baixa}

São várias as formas de se medir a produtividade do trabalho na indústria. Dependendo da disponibilidade das informações, é possível construir indicadores de produtividade física ou indicadores com valores monetários. A Pesquisa Industrial Mensal (PIM-IBGE), por exemplo, oferece as variáveis produção física (quantidades), pessoal ocupado e horas pagas, podendo-se gerar um quociente que expresse a quantidade média produzida por cada trabalhador ou, alternativamente, a quantidade média produzida por hora paga. Estas são duas medidas de produtividade física, já que têm no numerador do quociente uma variável de quantum. As PIAs, fonte de dados deste trabalho, oferecem apenas a possibilidade de se medir a produtividade monetária. A forma consagrada de construir tal medida é dada pelo quociente entre VTI e pessoal ocupado (PO), ou seja, avalia-se quanto cada trabalhador, em média, agregou valor, considerando-se o VTI como uma proxy de valor adicionado.

(20) O exame da evolução do coeficiente das 18 atividades da indústria de transformação brasileira ajuda a, pelo menos, "localizar" o fenômeno. Em cinco destas atividades, que juntas perfazem aproximadamente $44 \%$ da estrutura industrial, o comportamento do coeficiente foi semelhante ao do total, elevação entre 2007 e 2010-2011 e volta ao nível de 2007 em 2014. São elas: produtos alimentícios, derivados do petróleo e de biocombustíveis, produtos de metal, máquinas e equipamentos e veículos automotores, reboques e carrocerias. Para uma crítica ao uso da relação VTI/VP como indicador de adensamento de cadeias produtivas, ver Torres e Cavalieri (2015). Estes autores argumentam que a relação é muito sensível ao câmbio e que falha na avaliação setorial intertemporal e na comparação intersetorial. 
Os primeiros anos da década de 1990 ficaram conhecidos como um período em que a indústria brasileira obteve grandes ganhos de produtividade em função da necessidade de se adequar aos novos tempos da abertura comercial, ou seja, a curvas de demanda mais elásticas. As ineficiências históricas eram tão grandes que foi possível, num primeiro momento, produzir tais ganhos através de ajustes simples, rápidos e baratos, baseados principalmente em dispensa de pessoal, e na maior parte das vezes sem investimentos significativos em novos equipamentos. Efetivamente, a literatura da época (Salm; Saboia; Carvalho, 1997; Bonelli; Fonseca, 1998; Moreira, 1999; Bonelli, 2000) dá conta de elevações expressivas da produtividade na indústria brasileira ${ }^{21}$. Contudo, as diferentes formas de medir a produtividade, com base em diferentes variáveis e em pesquisas com metodologias e amostras distintas, geram resultados por vezes nada parecidos. Moreira (1999, p. 320) mostra isto com clareza, ao comparar os resultados com base na PIA, na PIM e nas Contas Nacionais, todas do IBGE. Nem mesmo a expectativa de que houvesse proximidade entre os números da PIA e das Contas Nacionais, por ambas trabalharem com o conceito de valor adicionado, se confirmou, e os resultados com base na PIA ficaram mais próximos dos calculados com base na PIM, apesar desta medir a variável produção física.

O ajuste mais rápido e fácil, alicerçado na redução do emprego industrial, se restringiu aos anos 1990. Conforme IEDI (2008), na década de 2000 os ganhos de produtividade - quando ocorreram, e neste caso medidos em termos físicos - podem ser considerados mais benignos, uma vez que se construíram até mesmo com uma recuperação do número de ocupados. A medida monetária, no entanto, já mostra estagnação e até suave queda da produtividade do trabalho nos anos 2000; para o período específico estudado neste artigo, 2007-2014, com base nas PIAs, a produtividade da Indústria de transformação sofreu uma redução de 5,3\% e a da Extrativa, uma alta de 66,1\%, em função do excepcional desempenho da atividade de Extração de petróleo e gás natural (Tabela 2) 22. Impressionam, neste período, as diferenças significativas de produtividade entre a Indústria extrativa e a de transformação nos anos selecionados.

Outras atividades que se destacaram positivamente foram Extração de minerais metálicos (28\%), Preparação de couros e fabricação de artefatos de couro, artigos para viagem e calçados (27\%), Confecção de artigos do vestuário e acessórios (26\%), Fabricação de móveis (21\%) e Fabricação de produtos alimentícios (15\%). Os destaques negativos foram Metalurgia (-32\%), Fabricação de produtos farmoquímicos e farmacêuticos (-23\%), Fabricação de veículos automotores, reboques e carrocerias (-19\%), Fabricação de bebidas (-17\%) e Fabricação de produtos químicos $(-11 \%)^{23}$. Assim, além de se sobressaírem as atividades ligadas à Indústria extrativa, certamente beneficiadas pelos

(21) No entanto, há que se considerar um provável viés para cima da medida de produtividade, tal como se observou anteriormente para a relação VTI/VP. Tanto quando se faz o cálculo com base na produção física, como quando se faz pelo VTI, os fenômenos do aumento das importações, em substituição à produção nacional, e da terceirização elevam "artificialmente" a medida da produtividade do trabalho.

(22) Contri (2015) mostra a evolução da produtividade e da folha de pagamento real por trabalhador para a Indústria de transformação brasileira, com base na Pesquisa Industrial Mensal - Produção Física e na Pesquisa Industrial Mensal Emprego e Salário, ambas do IBGE, para o período 2002-2014. Naturalmente, dadas as fontes alternativas em relação à deste trabalho, os resultados são um pouco diferentes, mas a tendência é a mesma.

(23) É importante deixar claro que a proposta deste ponto do trabalho é apontar as variações de produtividade das diversas atividades e mostrar suas diferenças, sem tentar explicar seus fatores determinantes. 
preços internacionais no período, deve-se chamar atenção para o fato de que as outras quatro atividades destacadas pertencem ao grupo das intensivas em trabalho. Ocorre, porém, que no período anterior (1996-2007), antes das mudanças metodológicas das PIAs, estas mesmas atividades tiveram desempenho muito ruim, com variações negativas de produtividade superiores a $20 \%{ }^{24}$. Ou seja, os ganhos de produtividade do período mais recente podem representar apenas um necessário ajuste depois das perdas do momento anterior $^{25}$.

Tabela 2

Produtividade da Indústria brasileira (VTI/PO), para anos selecionados, em R \$ mil

\begin{tabular}{|c|c|c|c|c|}
\hline & 2007 & 2011 & 2014 & $\begin{array}{l}\text { Variação \% } \\
(2007-2014)\end{array}$ \\
\hline Total & 131,9 & 133,8 & 130,5 & $-1,0$ \\
\hline Indústrias extrativas & 263,9 & 565,3 & 438,5 & 66,1 \\
\hline Extração de petróleo e gás natural & 392,6 & $3.264,0$ & $4.623,6$ & $1.077,6$ \\
\hline Extração de minerais metálicos & 556,5 & $1.188,9$ & 711,1 & 27,8 \\
\hline Indústrias de transformação & 129,1 & 123,7 & 122,3 & $-5,3$ \\
\hline Fabricação de produtos alimentícios & 88,4 & 97,3 & 101,6 & 14,9 \\
\hline Fabricação de bebidas & 248,0 & 223,0 & 206,8 & $-16,6$ \\
\hline Fabricação de produtos têxteis & 56,5 & 58,1 & 56,8 & 0,5 \\
\hline Confecção de artigos do vestuário e acessórios & 30,6 & 37,3 & 38,6 & 26,2 \\
\hline $\begin{array}{l}\text { Prep. de couros e fab. artef. couro, artigos viagem } \\
\text { e calçados }\end{array}$ & 34,6 & 38,2 & 43,8 & 26,9 \\
\hline Fabricação de celulose, papel e produtos de papel & 183,9 & 171,4 & 171,3 & $-6,8$ \\
\hline $\begin{array}{l}\text { Fabricação de coque, deriv. do petróleo e de } \\
\text { biocombustíveis }\end{array}$ & 697,7 & 973,0 & 768,5 & 10,1 \\
\hline Fabricação de produtos químicos & 272,1 & 240,2 & 240,8 & $-11,5$ \\
\hline $\begin{array}{l}\text { Fabricação de produtos farmoquímicos e } \\
\text { farmacêuticos }\end{array}$ & 276,3 & 225,8 & 213,4 & $-22,8$ \\
\hline $\begin{array}{l}\text { Fabricação de produtos de borracha e de material } \\
\text { plástico }\end{array}$ & 84,3 & 86,7 & 91,1 & 8,1 \\
\hline Fabricação de produtos de minerais não-metálicos & 82,7 & 86,2 & 84,9 & 2,7 \\
\hline Metalurgia & 335,1 & 211,4 & 226,7 & $-32,3$ \\
\hline $\begin{array}{l}\text { Fabricação de prod. de metal, exceto máquinas e } \\
\text { equipamentos }\end{array}$ & 77,5 & 75,6 & 73,6 & $-5,0$ \\
\hline $\begin{array}{l}\text { Fabricação de equip. de informática, prod. } \\
\text { eletrônicos e ópticos }\end{array}$ & 164,6 & 138,5 & 154,9 & $-5,9$ \\
\hline $\begin{array}{l}\text { Fabricação de máquinas, aparelhos e materiais } \\
\text { elétricos }\end{array}$ & 121,5 & 113,5 & 111,1 & $-8,6$ \\
\hline Fabricação de máquinas e equipamentos & 119,3 & 118,6 & 111,2 & $-6,8$ \\
\hline $\begin{array}{l}\text { Fabricação de veículos automotores, reboques e } \\
\text { carrocerias }\end{array}$ & 197,1 & 201,1 & 159,6 & $-19,0$ \\
\hline Fabricação de móveis & 43,9 & 50,5 & 53,3 & 21,4 \\
\hline
\end{tabular}

Fonte: Elaboração própria com base nas PIAs 2007, 2011 e 2014 - IBGE.

Nota: a preços de 2014, deflacionados pelo IGP-DI.

(24) Cálculos feitos pelo autor com base nas PIAs. Sobre as variações de produtividade da Indústria brasileira no período 1996-2006, ver IEDI (2008), e para 1996-2007, Galeano e Feijó (2013).

(25) Tal ajuste, depois de um período de resultados tão ruins, pode até mesmo estar escondendo mudanças estruturais dentro de cada atividade, como fusões e aquisições, mudanças geográficas e fechamento e abertura de unidades e/ou empresas. 


\section{Despesa com pessoal em alta}

Há diversas maneiras de se avaliar o tema da remuneração da mão de obra de uma empresa, de uma atividade industrial ou mesmo da indústria como um todo. Dependendo dos objetivos, deve-se privilegiar a ótica dos trabalhadores ou, alternativamente, a ótica da empresa. Neste artigo se privilegiou a ótica da empresa e, sendo assim, para medir o custo com pessoal, utilizou-se uma variável que engloba todos os custos que as empresas incorrem ao contratar mão de obra. Nas PIAs, esta variável é denominada Custos e despesas - gastos de pessoal - total.

A Tabela 3 mostra a evolução desta variável no período 2007-2014, em que sua taxa de crescimento foi de $14 \%$ para o total da Indústria brasileira, com uma grande diferença entre a variação da Indústria extrativa (64\%), majoritariamente influenciada pela atividade de Extração de petróleo e gás natural (228\%), e a da Indústria de transformação (12\%).

Tabela 3

Taxas de variação das despesas com pessoal da Indústria brasileira entre 2007 e 2014

\begin{tabular}{|c|c|c|c|}
\hline & $\begin{array}{c}\text { Variação \% da } \\
\text { despesa média anual } \\
\text { com pessoal (em R\$ } \\
\text { mil de 2014) }\end{array}$ & $\begin{array}{c}\text { Variação \% da } \\
\text { despesa média anual } \\
\text { com pessoal (em } \\
\text { US\$ mil) }\end{array}$ & $\begin{array}{c}\text { Variação da relação } \\
\text { despesa com } \\
\text { pessoal/despesa } \\
\text { total, em pp (1) }\end{array}$ \\
\hline Total & 14,4 & 45,5 & 0,8 \\
\hline Indústrias extrativas & 63,8 & 108,3 & 5,7 \\
\hline Extração de petróleo e gás natural & 227,7 & 316,8 & $-7,7$ \\
\hline Extração de minerais metálicos & 44,5 & 83,7 & 6,6 \\
\hline Indústrias de transformação & 12,4 & 42,9 & 0,6 \\
\hline Fabricação de produtos alimentícios & 24,0 & 57,6 & 1,0 \\
\hline Fabricação de bebidas & 5,2 & 33,8 & 0,4 \\
\hline Fabricação de produtos têxteis & 6,2 & 35,1 & 1,2 \\
\hline Confecção de artigos do vestuário e acessórios & 20,9 & 53,7 & 2,3 \\
\hline $\begin{array}{l}\text { Prep. De couros e fab. Artef. Couro, artigos viagem e } \\
\text { calçados }\end{array}$ & 12,1 & 42,5 & 1,4 \\
\hline Fabricação de celulose, papel e produtos de papel & $-0,1$ & 27,0 & $-0,4$ \\
\hline $\begin{array}{l}\text { Fabricação de coque, deriv. Do petróleo e de } \\
\text { biocombustíveis }\end{array}$ & 60,1 & 103,7 & $-1,6$ \\
\hline Fabricação de produtos químicos & 1,7 & 29,4 & 0,6 \\
\hline Fabricação de produtos farmoquímicos e farmacêuticos & $-0,8$ & 26,2 & $-1,8$ \\
\hline Fabricação de produtos de borracha e de material plástico & 8,3 & 37,7 & 0,5 \\
\hline Fabricação de produtos de minerais não-metálicos & 17,1 & 48,9 & $-0,1$ \\
\hline Metalurgia & 10,1 & 40,0 & 1,9 \\
\hline $\begin{array}{l}\text { Fabricação de prod. De metal, exceto máquinas e } \\
\text { equipamentos }\end{array}$ & 12,9 & 43,6 & 3,4 \\
\hline $\begin{array}{l}\text { Fabricação de equip. de informática, prod. Eletrônicos e } \\
\text { ópticos }\end{array}$ & 8,7 & 38,2 & 0,5 \\
\hline Fabricação de máquinas, aparelhos e materiais elétricos & 4,8 & 33,3 & 2,4 \\
\hline Fabricação de máquinas e equipamentos & 10,1 & 40,0 & 2,1 \\
\hline $\begin{array}{l}\text { Fabricação de veículos automotores, reboques e } \\
\text { carrocerias }\end{array}$ & $-0,2$ & 26,9 & 1,0 \\
\hline Fabricação de móveis & 20,8 & 53,7 & 4,0 \\
\hline
\end{tabular}

Fonte: Elaboração própria com base nas PIAs 2007 e 2014 - IBGE e Ipeadata.

(1) pontos percentuais. 
Como se comentou anteriormente, os preços internacionais das commodities sofreram oscilações a partir da crise de 2008, mas entre 2007 e 2014 houve elevação média de 27\%, com o petróleo cru subindo 35\% e o minério de ferro, 164\%, conforme IMF Data (2016). Estes preços em alta certamente ajudaram a sustentar custos maiores com pessoal para estas atividades ${ }^{26}$, mas, como será visto a seguir, não foram suficientes para evitar a queda da rentabilidade, principalmente a partir de 2011.

Do ponto de vista doméstico, o principal componente para explicar a elevação generalizada dos gastos com pessoal é a continuidade da política de aumentos reais do salário mínimo. Considerando-se o papel do salário mínimo como referência para os demais salários na economia brasileira, especialmente nas faixas mais baixas, como no caso da maioria dos trabalhadores da Indústria, é necessário que se faça esta relação. Deflacionado pelo IGP-DI - para manter o mesmo índice usado nas demais variáveis deste trabalho -, o salário mínimo real teve alta de $26 \%$ no período estudado (30\%, se for usado o INPC). Como se vê, o aumento médio real dos gastos com pessoal na Indústria brasileira (14\%) foi inferior ao aumento real do mínimo.

A política de aumentos reais do mínimo fez com que os trabalhadores da base da pirâmide salarial, portanto, das camadas mais próximas ao piso, ainda que acima desta referência, tivessem ganhos iguais ou semelhantes aos do mínimo, por estarem protegidos legalmente e/ou pelos bons resultados que seus sindicatos obtiveram nas negociações anuais. No caso dos trabalhadores com remunerações médias e altas na estrutura salarial, notam-se ganhos menores que os do mínimo no período 2007-2014, puxando a média para baixo $^{27}$. De qualquer forma, tal média para a Indústria brasileira foi superior aos ganhos de produtividade que, conforme visto, foram pequenos no período, quando não negativos.

Esta relação entre aumentos das despesas com pessoal e variação da produtividade abre outra questão: a da redução da competitividade das empresas brasileiras frente aos concorrentes estrangeiros, tanto no mercado interno quanto no internacional. Se já é claro o problema quando se observa a variação salarial média em reais constantes, o tema tornase ainda mais relevante quando se medem os aumentos de gastos com pessoal em dólares. Com efeito, a segunda coluna da Tabela 3 mostra que, dada a valorização da moeda nacional no período - a taxa de câmbio nominal, dólar comercial, variou $21 \%$ entre 2007 e 2014 e o IGP-DI variou 54\% -, a despesa média com pessoal cresceu 45\% em dólares, bem acima dos $14 \%$ medidos em reais constantes. Ainda na medida em dólares, chamam a atenção as grandes variações na Indústria extrativa (do total e de suas duas atividades) e

(26) Especialmente no caso da exploração do petróleo do Pré-Sal, que pela sua originalidade exigiu muitos investimentos e muitas contratações de pessoal altamente qualificado, o custo com pessoal subiu rapidamente. Em contrapartida, o preço internacional do petróleo em alta funcionou como estímulo adicional.

(27) Deve-se observar que três atividades intensivas em mão de obra e, portanto, com grande número de trabalhadores de baixa qualificação e com salários próximos ao mínimo, tiveram os maiores aumentos de despesa média com pessoal na Indústria de transformação, de mais de $20 \%$ entre 2007 e 2014. São elas: Fabricação de produtos alimentícios, Confecção de artigos do vestuário e acessórios e Fabricação de móveis, as duas últimas com ganhos destacados de produtividade que, certamente, apoiaram os aumentos de despesa com pessoal. Acima destas três há apenas o caso de Fabricação de coque, derivados do petróleo e de biocombustíveis (60\%). 
também da atividade que engloba a fabricação de derivados do petróleo e de biocombustíveis, todas viabilizadas pelos preços internacionais deste período.

Outra forma de ver o avanço das despesas com pessoal está expressa na terceira coluna da Tabela 3; ela mede a variação da relação entre o total das despesas com pessoal e as despesas totais das empresas industriais brasileiras no período estudado. Verifica-se que, para o total da Indústria, a relação cresceu 0,8 ponto percentual; o peso das despesas com pessoal nas despesas totais passou de 13,0\% em 2007 para 13,8\% em 2014. Destaquese o fato de aparecerem variações negativas para as atividades de Extração de petróleo e gás natural, Fabricação de coque, derivados do petróleo e de biocombustíveis e Fabricação de produtos farmoquímicos e farmacêuticos, mesmo num contexto de elevação de salários. Para a primeira destas três atividades, há uma explicação: os Custos com operações industriais aumentaram muito em proporção das despesas totais (de 19,4\% em 2007 para $32,4 \%$ em 2014), avançando sobre a fatia dos salários. As elevadas despesas operacionais para as primeiras fases de exploração do Pré-Sal justificam esta alta dos Custos com operações industriais. Já no caso dos derivados do petróleo, a alta dos preços internacionais do petróleo deve ajudar a explicar a queda da relação entre o total das despesas com pessoal e as despesas totais.

\section{Rentabilidade cada vez mais estreita}

Dada a disponibilidade das informações das PIAs, buscou-se medir a variável rentabilidade da forma mais ampla possível. Para tanto, tomou-se o quociente entre a Receita total e a Despesa total das empresas em forma de percentual ${ }^{28}$. Como se viu nas seções anteriores, a Indústria brasileira não logrou aumentos de produtividade no período estudado, mas aumentou suas despesas médias com pessoal em termos reais (Gráfico 2). Entre 2007 e 2014, as despesas médias com pessoal cresceram 14\% e a produtividade caiu $1 \%$ para o total da Indústria; as mesmas variáveis tiveram variação de $12 \%$ e $-5 \%$, respectivamente, se medidas somente para a Indústria de transformação. Tais ganhos salariais não acompanhados por elevações de produtividade do trabalho e, em muitas atividades, até mesmo acompanhados por variações negativas da produtividade, levaram a uma situação de estreitamento quase generalizado da rentabilidade ${ }^{29}$.

(28) A medida da rentabilidade também foi feita de maneira alternativa, restringindo-se aos itens operacionais; excluíram-se receitas e despesas não operacionais e custo das mercadorias adquiridas para revenda, por exemplo. Os resultados finais foram praticamente iguais.

(29) O Custo unitário do trabalho (CUT), excelente indicador de competitividade internacional, é dado pelo quociente entre o salário médio em dólares e a produtividade física da Indústria. Dada a evolução destas variáveis, o Banco Central do Brasil informa que o CUT aumentou $43 \%$ entre 2007 e 2014, o que mostra a dificuldade enfrentada pela Indústria brasileira no período. Tomou-se como referência a informação do Banco Central para o total da Indústria porque as PIAs não fornecem informações sobre a produção física, o que impossibilita o cálculo do CUT. Sobre a influência da taxa de câmbio e da produtividade nas importações da Indústria nacional, ver Faleiros et al. (2016). 
Gráfico 2

Índices de variáveis selecionadas da Indústria de transformação brasileira $(2007=100)$ - 2007/2014

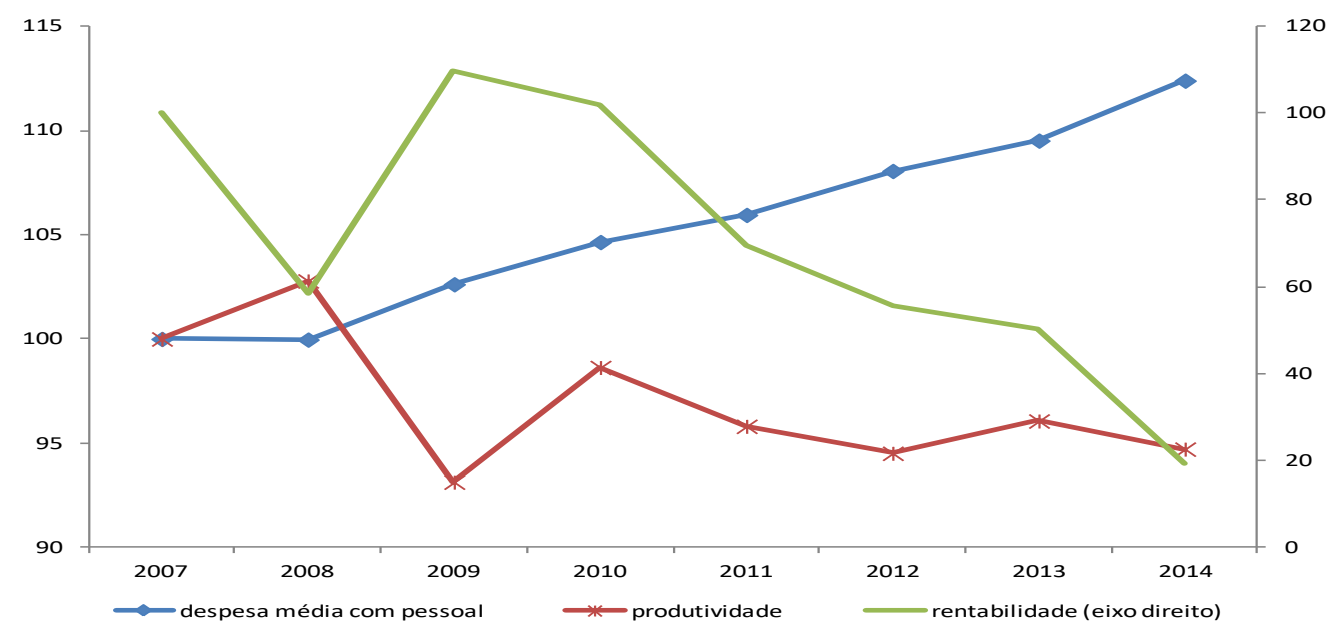

Fonte dos dados brutos: PIAs - IBGE.

A despeito da elevação das despesas médias com pessoal, o peso de tais despesas nas despesas totais quase não se alterou, oscilando entre $13 \%$ e $14 \%$ para o total da Indústria, o que pode ser considerado um percentual relativamente baixo. Uma conclusão apressada é que, com tal participação na estrutura global de custos, os ganhos salariais deveriam influenciar pouco a evolução da rentabilidade. Porém, deve-se considerar que, além de sua relação direta com a estrutura de custos das empresas, as despesas com pessoal compõem os custos das empresas ao longo das várias cadeias produtivas, ou seja, custos com pessoal se transformam em preços de matérias-primas e reaparecem como parte dos Custos com operações industriais (COI). O COI aumentou 13\% em termos reais entre 2007 e 2014, mas como proporção da despesa total até caiu, passando de $54 \%$ para $47 \%$ para o total da Indústria no período.

A Tabela 4 mostra como se comportou a relação percentual entre a Receita total e a Despesa total da Indústria brasileira entre 2007-2014, ou seja, quanto a Receita foi superior (ou, raramente, inferior) à Despesa, uma medida de rentabilidade. Para o total da Indústria, por exemplo, a Receita era 11\% superior à Despesa em 2007 e, apenas 2\% superior em 2014, uma queda expressiva. Contudo, é preciso observar que a variação da rentabilidade, ponta a ponta, é negativamente influenciada pelos resultados muito ruins dos últimos anos, em especial por 2014. Uma medida com menos viés pode ser feita pela média dos dois quadriênios do período estudado. Efetivamente, tanto para o total da Indústria, como para a Indústria de transformação, há quedas entre 2007-2010 e 2011-2014, mas tais quedas são bem menos pronunciadas que as verificadas na avaliação ponta a ponta. No primeiro quadriênio a média da rentabilidade da Indústria brasileira foi de $10,6 \%$ e no segundo, $5,7 \%$. Chama atenção as diferenças significativas de rentabilidade entre a Indústria extrativa e a de transformação, tanto no primeiro como no segundo quadriênio. Ocorre que tal diferença é justificada pela performance da extração de minerais metálicos, com excelente resultado, já que a extração de petróleo teve rentabilidade baixa no primeiro quadriênio e até mesmo negativa no segundo, aproximando-se do desempenho da Indústria de transformação. 
Tabela 4

Rentabilidade da Indústria brasileira (Receita total/Despesa total, em \%), para anos selecionados

\begin{tabular}{|c|c|c|c|c|c|}
\hline & 2007 & 2014 & $\begin{array}{c}\text { Média } \\
2007-2010 \\
\end{array}$ & $\begin{array}{c}\text { Média } \\
2011-2014 \\
\end{array}$ & $\begin{array}{c}\text { Variação } \\
\%\end{array}$ \\
\hline Total & 11,5 & 2,0 & 10,6 & 5,7 & $-46,1$ \\
\hline Indústrias extrativas & 46,9 & 3,8 & 48,5 & 23,6 & $-51,4$ \\
\hline Extração de petróleo e gás natural & 27,2 & $-12,3$ & 11,5 & $-1,6$ & $-113,6$ \\
\hline Extração de minerais metálicos & 54,6 & 10,0 & 62,3 & 34,6 & $-44,4$ \\
\hline Indústrias de transformação & 10,0 & 1,9 & 9,3 & 4,9 & $-47,4$ \\
\hline Fabricação de produtos alimentícios & 1,7 & 2,2 & 1,6 & 1,7 & 4,6 \\
\hline Fabricação de bebidas & 15,1 & 23,2 & 24,6 & 28,3 & 15,0 \\
\hline Fabricação de produtos têxteis & 2,3 & 2,6 & 3,5 & 3,9 & 11,2 \\
\hline Confecção de artigos do vestuário e acessórios & 11,3 & 14,4 & 10,0 & 14,8 & 47,4 \\
\hline $\begin{array}{l}\text { Prep. de couros e fab. artef. couro, artigos viagem } \\
\text { e calçados }\end{array}$ & 5,4 & 9,6 & 7,4 & 8,3 & 12,2 \\
\hline Fabricação de celulose, papel e produtos de papel & 12,5 & 3,5 & 5,0 & 2,5 & $-49,6$ \\
\hline $\begin{array}{l}\text { Fabricação de coque, deriv. do petróleo e de } \\
\text { biocombustíveis }\end{array}$ & 22,3 & $-8,9$ & 23,2 & 5,8 & $-75,1$ \\
\hline Fabricação de produtos químicos & 7,9 & 2,2 & 5,4 & 3,5 & $-34,2$ \\
\hline $\begin{array}{l}\text { Fabricação de produtos farmoquímicos e } \\
\text { farmacêuticos }\end{array}$ & 12,6 & 8,1 & 11,4 & 9,6 & $-15,9$ \\
\hline $\begin{array}{l}\text { Fabricação de produtos de borracha e de material } \\
\text { plástico }\end{array}$ & 4,4 & 4,4 & 4,9 & 4,4 & $-10,5$ \\
\hline Fabricação de produtos de minerais não-metálicos & 9,6 & $-0,3$ & 13,4 & 8,5 & $-36,4$ \\
\hline Metalurgia & 23,1 & 2,5 & 14,8 & 0,6 & $-95,9$ \\
\hline $\begin{array}{l}\text { Fabricação de prod. de metal, exceto máquinas e } \\
\text { equipamentos }\end{array}$ & 12,6 & 8,4 & 12,5 & 9,6 & $-23,1$ \\
\hline $\begin{array}{l}\text { Fabricação de equip. de informática, prod. } \\
\text { eletrônicos e ópticos }\end{array}$ & 7,3 & 1,1 & 4,1 & 1,6 & $-60,4$ \\
\hline $\begin{array}{l}\text { Fabricação de máquinas, aparelhos e materiais } \\
\text { elétricos }\end{array}$ & 5,7 & 2,6 & 6,1 & 3,7 & $-39,2$ \\
\hline Fabricação de máquinas e equipamentos & 8,4 & 4,0 & 8,0 & 5,5 & $-31,6$ \\
\hline $\begin{array}{l}\text { Fabricação de veículos automotores, reboques e } \\
\text { carrocerias }\end{array}$ & 7,9 & $-0,6$ & 8,7 & 3,4 & $-61,0$ \\
\hline Fabricação de móveis & 5,5 & 7,6 & 7,0 & 8,6 & 21,3 \\
\hline
\end{tabular}

Fonte: Elaboração própria com base nas PIAs - IBGE.

A última coluna da Tabela mostra a variação percentual da rentabilidade entre os dois quadriênios e dá uma boa ideia de sua redução para a Indústria nacional no período. As duas atividades da Indústria extrativa sofreram diminuição de rentabilidade, muito mais expressiva para Extração de petróleo e gás natural, inclusive com Despesas maiores que Receitas entre 2012 e 2014, constituindo o único caso de rentabilidade média negativa no segundo quadriênio. Das 18 atividades da Indústria de transformação, apenas seis tiveram variação positiva da rentabilidade entre os dois quadriênios e, mesmo assim, variações pequenas, com exceção de Confecção de artigos do vestuário e acessórios (47\%). Também é importante observar que quatro destas seis aumentaram muito pouco sua rentabilidade média e, mais ainda, que tais aumentos se deram sobre níveis reduzidos desta variável no primeiro quadriênio, abaixo de $7 \%$. 


\section{Investimento em marcha lenta}

Com a rentabilidade em queda e as perspectivas de crescimento da economia abaladas pela crise internacional a partir de 2008/2009 e pelos desajustes domésticos (controle de preços administrados, controle do câmbio, juros elevados e mudança das regras das concessões de serviços públicos), agravados no período 2012-2014, não se deveriam esperar avanços significativos dos investimentos na Indústria brasileira $^{30}$. Com efeito, o que se verificou foi uma expansão moderada da variável entre 2007 e 2014, 17\% em termos reais, próxima da expansão do VP (16\%) e pouco abaixo da do VTI (21\%). A Tabela 5 ilustra a evolução da variável sob diversas formas ${ }^{31}$.

Tabela 5

Investimento da Indústria brasileira entre 2007 e 2014

\begin{tabular}{l|c|c|c|c}
\hline & $\begin{array}{c}\text { Variação } \% \\
\text { do } \\
\text { investimento } \\
(1)\end{array}$ & $\begin{array}{c}\text { Difusão do } \\
\text { investimento } \\
\text { em 2011- } \\
2014\end{array}$ & $\begin{array}{c}\text { Variação } \\
\text { difusão } \\
(1)\end{array}$ & $\begin{array}{c}\text { Relação } \\
\text { I/VTI em } \\
2011- \\
2014\end{array}$ \\
\hline Total & 16,7 & 35,6 & 9,2 & 19,4 \\
\hline Indústrias extrativas & 155,9 & 41,7 & 27,3 & 30,1 \\
\hline Extração de petróleo e gás natural & $5.615,6$ & 81,6 & 27,4 & 93,0 \\
\hline Extração de minerais metálicos & 76,9 & 53,5 & $-7,4$ & 25,4 \\
\hline Indústrias de transformação & 7,0 & 35,5 & 8,9 & 18,3 \\
\hline Fabricação de produtos alimentícios & 5,6 & 35,1 & 11,2 & 14,9 \\
\hline Fabricação de bebidas & 34,0 & 50,4 & 5,8 & 18,4 \\
\hline Fabricação de produtos têxteis & $-13,8$ & 34,7 & $-7,2$ & 12,4 \\
\hline Confecção de artigos do vestuário e acessórios & 43,3 & 24,2 & 19,2 & 5,6 \\
\hline Prep. de couros e fab. artef. couro, artigos viagem e calçados & 5,1 & 31,7 & 0,6 & 6,8 \\
\hline Fabricação de celulose, papel e produtos de papel & $-15,8$ & 44,1 & 10,1 & 23,9 \\
\hline Fabricação de coque, deriv. do petróleo e de biocombustíveis & 10,2 & 77,6 & $-9,6$ & 39,9 \\
\hline Fabricação de produtos químicos & $-1,2$ & 51,2 & 3,6 & 15,3 \\
\hline Fabricação de produtos farmoquímicos e farmacêuticos & 3,9 & 74,9 & 7,3 & 9,2 \\
\hline Fabricação de produtos de borracha e de material plástico & 10,3 & 44,7 & 7,9 & 16,8 \\
\hline Fabricação de produtos de minerais não-metálicos & 50,7 & 33,0 & 25,6 & 21,1 \\
\hline Metalurgia & $-35,7$ & 45,9 & 0,7 & 20,2 \\
\hline Fabricação de prod. de metal, exceto máquinas e & & & & \\
equipamentos & 12,0 & 33,2 & $-2,1$ & 11,1 \\
\hline Fabricação de equip. de informática, prod. eletrônicos e & 13,2 & 52,1 & 6,4 & 8,7 \\
\hline ópticos & 0,6 & 50,2 & 2,6 & 9,2 \\
\hline Fabricação de máquinas, aparelhos e materiais elétricos & 16,5 & 52,8 & 11,8 & 10,4 \\
\hline Fabricação de máquinas e equipamentos & 53,2 & 41,8 & $-7,1$ & 16,9 \\
\hline Fabricação de veículos automotores, reboques e carrocerias & 22,9 & 38,3 & 38,5 & 9,2 \\
\hline Fabricação de móveis & & & & \\
\hline Fonte: Elato & & & \\
\hline
\end{tabular}

Fonte: Elaboração própria com base nas PIAs - IBGE.

(1) entre os quadriênios 2007-2010 e 2011-2014.

(30) Ainda que o controle dos preços administrados e do câmbio possam, num primeiro momento, beneficiar algumas atividades, a perspectiva bem realista de um ajuste futuro traz insegurança aos planos de investimento das empresas.

(31) Dada a natureza instável da variável Investimento, optou-se por medir sua taxa de variação através da sua média nos dois quadriênios que compõem o período estudado, 2007-2010 e 2011-2014, evitando-se assim um possível viés pelos valores - altos ou baixos demais - de um único ano. O mesmo foi feito para a variação da difusão do investimento. Ademais, estes dois quadriênios representam exatamente os dois períodos de Governo, Lula II e Dilma I. 
De imediato, destaca-se o crescimento dos investimentos da atividade Extração de petróleo e gás natural, certamente influenciados pelo mercado internacional e pelos avanços da exploração nacional das novas reservas, sobretudo as da camada do Pré-Sal. Só sob circunstâncias tão especiais, e também pelo fato de que o primeiro quadriênio teve valores muito baixos, é possível interpretar tal expansão, que acabou por elevar a média da Indústria extrativa e até mesmo a média geral, já que a Indústria de transformação teve alta dos investimentos de apenas $7 \%$.

Ainda destacam-se as expansões dos investimentos de mais seis atividades: Extração de minerais metálicos (77\%), Fabricação de bebidas (34\%), Confecção de artigos do vestuário e acessórios (43\%), Fabricação de produtos de minerais não-metálicos (51\%), Fabricação de veículos automotores, reboques e carrocerias (53\%) e Fabricação de móveis (23\%). É importante observar que estas atividades são praticamente as mesmas destacadas na seção 2 deste trabalho, quando se verificava quais atividades tinham ganho espaço na estrutura industrial brasileira, seja respondendo a estímulos externos ou domésticos; a única exceção aqui é a inclusão de Bebidas. Isto leva à conclusão de que tais estímulos não só causaram efeitos na produção do período examinado, mas também foram suficientes para que as empresas fizessem apostas em relação à continuidade da expansão de sua demanda, que deveria ser atendida com as novas plantas e as melhorias tecnológicas propiciadas pelos investimentos. Como se sabe, a recessão que se estabeleceu a seguir, no biênio 2015-2016, ou sustou projetos ainda em construção ou fez com que aumentasse o percentual de capacidade ociosa das plantas em que os investimentos foram concluídos, do que a indústria automobilística constitui um exemplo eloquente.

Os destaques negativos ficam por conta de Fabricação de produtos têxteis, Fabricação de celulose, papel e produtos de papel, Fabricação de produtos químicos e Metalurgia, esta com expressiva queda de $36 \%$ do volume de investimentos. Novamente aqui há uma relação com o que se verificou na seção 2 deste trabalho, isto é, as atividades que perderam espaço na produção são as que tiveram queda nos investimentos.

As duas colunas seguintes da Tabela 5 informam sobre a difusão do investimento. Esta variável revela a parcela (medida em percentual) do total de empresas de um grupo específico - uma atividade ou a indústria como um todo - que fizeram algum tipo de investimento em um determinado período, seja de aquisição ou de melhoria. É o que se poderia chamar de taxa de difusão do investimento, ou seja, o percentual de empresas investidoras em relação ao total de empresas de determinada atividade. Observa-se novamente a atividade Extração de petróleo e gás natural; ela é a que teve o maior indicador de difusão no segundo quadriênio e a segunda maior taxa de crescimento da difusão, apenas atrás de Fabricação de móveis. Tal fato não deve surpreender, visto que a extração de petróleo e gás é uma atividade intensiva em tecnologia e que estava se expandindo rapidamente neste período no Brasil em função da exploração das novas reservas de petróleo em águas profundas, o que atraiu novas empresas, inclusive muitas de capital estrangeiro.

Também não surpreende que o ranking das atividades de difusão seja liderado por indústrias extrativas, pela produtora de derivados de petróleo e de biocombustíveis e por indústrias intensivas em tecnologia e em capital. Como se poderia esperar, na parte de baixo 
do ranking ficam as indústrias tradicionais, que usam mais o preço como atributo de competição e menos a diferenciação do produto, esta alcançada através de maiores investimentos (Guimarães, 1982). Já no que se refere à variação da difusão entre os dois quadriênios, não há um padrão definido de acordo com qualquer classificação usual para a Indústria. Atividades tradicionais avançaram em meio a não tradicionais e atividades destacadas no quadriênio 2011-2014 até tiveram queda do indicador de difusão entre os dois quadriênios. Chama atenção a fabricação de derivados de petróleo e de biocombustíveis, segunda maior no ranking do quadriênio 2011-2014 e a maior queda entre os dois quadriênios $(-9,6 \%)$; isto se deve ao fato de o percentual do primeiro quadriênio já ser muito elevado $(85,8 \%)$.

A última coluna da Tabela 5 traz a relação entre o valor do investimento e o do VTI para o segundo quadriênio, conhecida como taxa de investimento (I/VTI). É importante referir que a taxa de 19,4\% para o total da Indústria entre 2011 e 2014 é muito semelhante à taxa de $19,0 \%$ do primeiro quadriênio. A diferença significativa não está no período estudado neste trabalho, mas sim na comparação com o período anterior, entre 1996 e 2007, quando a taxa média foi de 16,3\% ${ }^{32}$, Ou seja, nos anos mais recentes (2007-2014), apesar de os investimentos não terem crescido muito (17\%), houve um esforço de investimento maior por parte das empresas, mesmo num contexto de queda da rentabilidade e da produtividade. Tendo em conta os diferentes padrões de competição das diversas atividades e o momento específico que cada uma delas vive é possível, hipoteticamente, arrolar elementos de motivação das empresas para justificar os investimentos num ambiente adverso. Alguns destes elementos são: aumentar a escala - para captar a elevação do mercado doméstico de bens salários -, oferecer contrapartida de incentivos fiscais, modernizar para enfrentar a concorrência externa e atender ao vetor de expansão do PréSal e da sua cadeia produtiva criada a partir da exigência de conteúdo local.

Assim como para tantas outras variáveis analisadas neste trabalho, a relação I/VTI também coloca em destaque a Indústria extrativa (30\%), especialmente pelo desempenho da atividade Extração de petróleo e gás natural que alcança a marca de $93 \%$ no segundo quadriênio ( $46 \%$ no primeiro quadriênio). A Indústria de transformação chega a apenas $18 \%$ no segundo quadriênio e há só uma atividade que vai bem além desta média: é a Fabricação de coque, derivados do petróleo e de biocombustíveis (40\%). Somente mais quatro atividades têm taxa acima da média da Indústria de transformação, sendo a maior delas a de Fabricação de celulose, papel e produtos de papel (24\%), e isto ocorre apesar de se observar queda de $16 \%$ no volume de investimentos para esta atividade entre os quadriênios 2007-2010 e 2011-2014.

Quanto à estrutura da Indústria brasileira, de acordo com a distribuição dos Investimentos por atividade, deve-se destacar a participação de derivados do petróleo e de biocombustíveis, com quase $30 \%$ do total no período estudado (Tabela 6). Ainda que se trate de uma indústria intensiva em capital e que sempre tem presença marcante na estrutura dos investimentos do País, sua participação até o início dos anos 2000 era bem menor, girando em torno de $8 \%$ a $10 \%$. A partir de 2001-2002 começou um ciclo de expansão que

(32) Se considerarmos somente a Indústria de transformação, a média da relação I/VTI para o período 1996-2007 foi de $16,0 \%$ e para $2007-2014,18,5 \%$. 
elevou muito rapidamente sua participação no total, a ponto de distorcer a medida de concentração dos investimentos.

Tabela 6

Estrutura da Indústria brasileira, de acordo com a distribuição do Investimento, entre 2007 e 2014

\begin{tabular}{l|c|c|c|c}
\hline & $\begin{array}{c}\text { Média } \\
2007-2010\end{array}$ & $\begin{array}{c}\text { Média } \\
2011-2014\end{array}$ & $\begin{array}{c}\text { Variação } \\
\text { em pp (1) }\end{array}$ & $\begin{array}{c}\text { Variação } \\
\%\end{array}$ \\
\hline Total & 100,0 & 100,0 & & \\
\hline Indústrias extrativas & 6,5 & 14,2 & 7,7 & 117,2 \\
\hline Extração de petróleo e gás natural & 0,1 & 4,6 & 4,5 & $4.620,9$ \\
\hline Extração de minerais metálicos & 5,6 & 8,4 & 2,8 & 50,8 \\
\hline Indústrias de transformação & 93,5 & 85,8 & $-7,7$ & $-8,2$ \\
\hline Fabricação de produtos alimentícios & 12,8 & 11,7 & $-1,1$ & $-9,2$ \\
\hline Fabricação de bebidas & 2,6 & 3,0 & 0,4 & 15,3 \\
\hline Fabricação de produtos têxteis & 1,3 & 1,0 & $-0,3$ & $-25,4$ \\
\hline Confecção de artigos do vestuário e acessórios & 0,5 & 0,7 & 0,2 & 22,6 \\
\hline Prep. de couros e fab. artef. couro, artigos viagem e calçados & 0,6 & 0,5 & $-0,1$ & $-9,6$ \\
\hline Fabricação de celulose, papel e produtos de papel & 4,9 & 3,5 & $-1,4$ & $-28,3$ \\
\hline Fabricação de coque, deriv. do petróleo e de biocombustíveis & 30,5 & 28,7 & $-1,8$ & $-5,7$ \\
\hline Fabricação de produtos químicos & 6,2 & 5,3 & $-0,9$ & $-14,9$ \\
\hline Fabricação de produtos farmoquímicos e farmacêuticos & 1,1 & 1,0 & $-0,1$ & $-10,6$ \\
\hline Fabricação de produtos de borracha e de material plástico & 3,1 & 3,0 & $-0,1$ & $-4,5$ \\
\hline Fabricação de produtos de minerais não-metálicos & 3,1 & 4,0 & 0,9 & 29,5 \\
\hline Metalurgia & 9,0 & 5,0 & $-4,0$ & $-44,5$ \\
\hline Fabricação de prod. de metal, exceto máquinas e & & & & \\
equipamentos & 2,1 & 2,0 & $-0,1$ & $-3,1$ \\
\hline Fabricação de equip. de informática, prod. eletrônicos e & & & & \\
\hline ópticos & 1,1 & 1,0 & $-0,1$ & $-2,0$ \\
\hline Fabricação de máquinas, aparelhos e materiais elétricos & 1,5 & 1,3 & $-0,2$ & $-13,5$ \\
\hline Fabricação de máquinas e equipamentos & 2,5 & 2,5 & 0,0 & 0,1 \\
\hline Fabricação de veículos automotores, reboques e carrocerias & 5,7 & 7,5 & 1,8 & 30,7 \\
\hline Fabricação de móveis & 0,6 & 0,6 & 0,0 & 5,6 \\
\hline Fonte: Elaboração propra com bas & & & \\
\hline
\end{tabular}

Fonte: Elaboração própria com base nas PIAs - IBGE.

(1) pontos percentuais.

Justamente para evitar tal distorção, calculou-se o peso das cinco atividades mais significativas no total dos investimentos da Indústria brasileira, excluindo-se a produtora de derivados do petróleo e de biocombustíveis. Desta forma, chega-se a 39,4\% no primeiro quadriênio e $37,9 \%$ no segundo. É importante observar que a lista destas cinco atividades não se alterou entre os dois quadriênios, mas Metalurgia sofreu uma queda relevante e Veículos e Extração de minerais metálicos tiveram avanços expressivos. A Indústria extrativa mais do que dobrou sua participação entre os dois quadriênios, de 6,5\% para 14,2\%, muito em função da atividade Extração de petróleo e gás natural.

Concluindo a seção sobre os investimentos, é forçoso reconhecer o avanço da Indústria extrativa e da atividade de derivados do petróleo e de biocombustíveis de acordo com as diversas variáveis investigadas. IEDI (2008) já havia chamado atenção para este ponto, para o período 1996-2006, manifestando sua preocupação com uma especialização da Indústria brasileira em commodities, o que representa um aumento da dependência do 
dinamismo do mercado internacional. O período 2017-2014 mostrou que a Indústria brasileira continuou se movendo na direção de uma participação maior destas atividades, $o$ que repõe a preocupação do trabalho do IEDI.

\section{Conclusão}

O período estudado neste trabalho corresponde quase integralmente ao momento em que cessou o pujante crescimento do mercado internacional a que se assistiu desde o início dos anos 2000. A crise financeira iniciada no final de 2008 lançou muitas dúvidas sobre a evolução da economia mundial e suas repercussões no Brasil, em especial sobre a Indústria, já que o desempenho anterior do setor havia sido muito influenciado pelo avanço de atividades ligadas à exploração de recursos naturais demandados pelos países líderes do crescimento do período. Tal avanço chegava até mesmo a causar inquietação sobre um exagerado e crescente grau de dependência destas atividades, ou seja, um grau de dependência da economia nacional em relação ao dinamismo do mercado internacional.

Contudo, o que se observou foi que, após sofrer um abalo inicial, principalmente em 2009, o mercado internacional de commodities logo se recuperou e os preços médios em 2014 foram semelhantes aos de 2008 e $27 \%$ mais altos que os de 2007. No Brasil as atividades ligadas à Indústria extrativa continuaram a ter um protagonismo cada vez maior por qualquer ângulo que se examine, em especial a que se dedica à exploração de petróleo e gás natural, beneficiada pelo início da operação dos campos da camada do Pré-Sal. Com ela também avançou muito a atividade de transformação dedicada à fabricação de derivados do petróleo e de biocombustíveis.

Contrariamente ao bom desempenho da Indústria extrativa, a Indústria de transformação teve uma performance fraca no período estudado e, claro, perdeu espaço na estrutura da Indústria brasileira, seja pelas variáveis VP e VTI, seja em relação aos investimentos ou ao emprego. É certo que, a despeito da perda de participação da Indústria de transformação, ela ainda representa a fatia majoritária da Indústria brasileira, com mais de $90 \%$ do VP e do VTI total. No interior da Indústria de transformação algumas atividades aproveitaram bem os impulsos gerados pelas políticas que beneficiaram as camadas mais pobres da população, tanto pela elevação do salário mínimo, como pela expansão do crédito ou ainda pela redução de impostos. Exemplos são as atividades de alimentação, vestuário, móveis e minerais não metálicos, esta por ser produtora de materiais para construção. A atividade de veículos, ainda que produza bens para consumidores com níveis de renda mais elevados, também se beneficiou de estímulos governamentais, como a redução de impostos e a expansão do crédito.

As variáveis mais diretamente vinculadas à operação e ao resultado econômico das empresas exprimiram bem as dificuldades da Indústria brasileira no período 2007-2014. Ainda que se mantenham diferenças significativas entre a Indústria extrativa e a de transformação, a combinação entre as variações da produtividade e das despesas com pessoal acabou por sacrificar quase generalizadamente a rentabilidade das empresas. Para a Indústria extrativa a produtividade até cresceu, mas as despesas com pessoal cresceram junto, e para a Indústria de transformação a produtividade caiu 5\% e os gastos com pessoal cresceram $12 \%$, fazendo com que fosse inevitável a queda da rentabilidade. 
Também no que se refere aos investimentos, ficou marcada a diferença entre as Indústrias extrativa e de transformação, com especial destaque para a atividade produtora de petróleo e gás natural. Ela dominou o cenário da expansão da capacidade e junto com a Extração de minerais metálicos desequilibrou todas as variáveis a favor da Indústria extrativa; basta ver o seu ganho de 7,7 pontos percentuais na estrutura dos investimentos da Indústria brasileira entre os dois quadriênios estudados. Recoloca-se, assim, o temor de algumas análises em relação ao fato de a Indústria nacional estar se movendo para uma situação de maior dependência do mercado internacional de commodities. Porém, tal como se observou no início da seção 2 , tal rearranjo de forças não deveria significar uma contraposição, no sentido de que o crescimento absoluto de um grupo de atividades deva levar ao sacrifício automático da expansão do outro.

Como se observou anteriormente, a crise internacional desencadeada a partir de 2008/2009 não confirmou os temores de que a quebra do ciclo de crescimento que se vivia até aquele momento gerasse uma abrupta redução de preços - e quantidades - no comércio internacional de commodities, o que impactaria negativamente países como o Brasil. Mas isto, é claro, não basta para eliminar o receio e as possíveis consequências negativas de se transformar a Indústria brasileira numa estrutura produtiva em que o peso das commodities seja cada vez maior - o que corresponde à noção de reprimarização - e, em contrapartida, diminua o peso das atividades mais intensivas em tecnologia e difusoras de progresso técnico. Sobre este ponto, sempre vale lembrar o quanto a política cambial colaborou para a diminuição da competitividade da Indústria de transformação nacional, ao aceitar e até induzir - pelo efeito do câmbio sobre a taxa de inflação - a apreciação do real ("flutuação suja"), cujas causas estão tanto nos saldos comerciais, inclusive do agronegócio, como no diferencial de taxas de juros doméstica versus internacional.

O panorama traçado neste trabalho muito provavelmente foi piorado pelos efeitos da recessão do meio da década de 2010, período em que a Indústria brasileira aprofundou ainda mais sua já longa agonia. As informações das pesquisas conjunturais de várias fontes permitem esta conclusão que deve ser confirmada quando da divulgação das PIAs, em especial no que se refere à evolução da rentabilidade e dos investimentos, com inevitável queda. O monitoramento deste processo é uma importante agenda de pesquisa que deve ser acompanhada, objetivando modelar ações de políticas públicas para o setor.

\section{Referências bibliográficas}

ALMEIDA, Júlio Sérgio Gomes de; NOVAIS, Luis Fernando. Indústria e política industrial no contexto pós-crise. In: NOVAIS, Luis Fernando et al. (Org.). A economia brasileira no contexto da crise global. São Paulo: Fundap, 2014.

AMATO NETO, João. "Desverticalização"/"terceirização" e as relações de subcontratação no complexo automobilístico brasileiro. Gestão \& Produção, São Carlos, Univ. Fed. São Carlos, v. 1, n. 1, abr. 1994.

ARAUJO, A.; FERRARI FILHO, F.; BUENO, E. Existe uma bolha imobiliária no Brasil? Uma análise teórica e empírica. Análise Econômica, Porto Alegre, FCE/UFRGS, ano 34, n. 66 , set. 2016. 
AVERBUG, André; GIAMBIAGI, Fabio. A crise brasileira de 1998/1999 - origens e consequiências. Rio de Janeiro: BNDES, 2000. (Texto para Discussão, n. 77).

BACHA, Edmar; BOLLE, Monica Baumgarten (Org.). O futuro da indústria no Brasil: desindustrialização em debate. Rio de Janeiro: Civilização Brasileira, 2013.

BELlUZZO, Luiz Gonzaga de Mello; ALMEIDA, Júlio Sérgio Gomes de. Depois da queda: a economia brasileira da crise da dívida aos impasses do Real. Rio de Janeiro: Civilização Brasileira, 2002.

BONELLI, Regis. Ganhos de produtividade na economia brasileira na década de 90: um retrato de corpo inteiro. Rio de Janeiro: Ipea, 2000. Mimeo.

BONELLI, Regis; FONSECA, Renato. Ganhos de produtividade e de eficiência: novos resultados para a economia brasileira. Pesquisa e Planejamento Econômico, Rio de Janeiro, v. 28, n. 2, ago. 1998.

BRESSER-PEREIRA, Luiz Carlos (Org.). Doença holandesa e indústria. Rio de Janeiro: FGV, 2010.

CALIXTRE, André Bojikian; BIANCARELLI, André Martins; CINTRA, Marcos Antônio M. (Org.). Presente e futuro do desenvolvimento brasileiro. Brasília: Ipea, 2014.

CARNEIRO, Ricardo. Navegando a contravento. Campinas: IE/Unicamp, mar. 2017. (Texto para Discussão, n. 289).

CASTRO, Antônio Barros de. A reestruturação industrial brasileira nos anos 90. Uma interpretação. Revista de Economia Política, São Paulo: Brasiliense, v. 21, n. 3, jul./set. 2001.

CONTRI, André L. O desempenho industrial brasileiro e as conjunturas nacional e internacional. Indicadores Econômicos FEE, Porto Alegre, v. 43, n. 1, 2015.

COUTINHO, Luciano; FERRAZ, João Calos. Estudo da competitividade da indústria brasileira. 3. ed. Campinas: Editora Papirus-Unicamp, 1995.

FALEIROS, João P. M.; SILVA, José C. D.; NAKAGUMA, Marcos Y. Evaluating the effect of exchange rate and labor productivity on import penetration of Brazilian manufacturing sectors. EconomiA, v. 17, n. 1, jan./abr. 2016.

FERRAZ, João Carlos; KUPFER, David; HAGUENAUER, Lia. Made in Brazil. Desafios competitivos para a indústria. Rio de Janeiro: Campus, 1995.

FLIGENSPAN, Flávio et al. As exportações do Brasil nos anos 2000: evolução, market share e padrões de especialização a partir de distintas agregações setoriais. Indicadores Econômicos FEE, Porto Alegre, v. 42, n. 4, 2015.

FUNCEX Data. Disponível em: http://www.funcexdata.com.br/. Acesso em: 17 mar. 2017.

FUNDAÇÃO GETULIO VARGAS. Índice de Confiança do Consumidor. Disponível em: http://www14.fgv.br/novo fgvdados/NaoIdentificado.aspx. Acesso em: 19 set. 2017. 
GALEANO, Edileuza; FEIJÓ, Carmen. A estagnação da produtividade do trabalho na indústria brasileira nos anos 1996-2007: análise nacional, regional e setorial. Nova Economia, Belo Horizonte, v. 23, n. 1, jan./abr. 2013.

GUIMARÃES, Eduardo Augusto. Acumulação e crescimento de firma: um estudo de Organização Industrial. Rio de Janeiro: Ed. Guanabara, 1987.

HIRATUKA, Célio; SARTI, Fernando. Transformações na estrutura produtiva global, desindustrialização e desenvolvimento industrial no Brasil. Revista de Economia Política, São Paulo, v. 37, n. 1, jan./mar. 2017.

IBGE. Pesquisa Industrial. Empresa. Rio de Janeiro, v. 33, n. 1, 2014.

IBGE. Pesquisa Industrial Anual. Disponível em: http://www.sidra.ibge.gov.br/. Acesso em: 15 mar. 2017.

IBGE. Pesquisa Industrial Mensal. Disponível em: http://www.sidra.ibge.gov.br/. Acesso em 19 set. 2017.

IBGE. Pesquisa Mensal do Comércio. Disponível em: http://www.sidra.ibge.gov.br/. Acesso em 15 mar. 2017.

IPEADATA. Disponível em: http://www.ipeadata.gov.br/. Acesso em 19 set. 2017.

IEDI. A evolução da estrutura industrial. São Paulo, 2008.

IEDI. Indústria, mudança estrutural e desenvolvimento. Carta IEDI, São Paulo, n. 759, nov. 2016.

IMF Data. Access to Macroeconomic \& Financial Data. Disponível em: http://data.imf.org/?sk=388DFA60-1D26-4ADE-B505-

A05A558D9A42\&sid=1393552803658\&ss=1479331931186. Acesso em: 16 mar. 2017.

IPEAdata. Disponível em: http://www.ipeadata.gov.br/. Acesso em: 15 mar. 2017.

MARCONI, Nelson; ROCHA, Marcos. Taxa de câmbio, comércio exterior e desindustrialização precoce - o caso brasileiro. Economia e Sociedade, Campinas, v. 21, número especial, dez. 2012.

MARCONI, Nelson; ROCHA, Igor L.; MAGACHO, Guilherme R. Sectoral capabilities and productive structure: an input-output analysis of the key sectors of the Brazilian economy. Revista de Economia Política, São Paulo, v. 36, n. 3, jul./set. 2016.

MOREIRA, Maurício Mesquita. A indústria brasileira nos anos 90 . O que já se pode dizer? In: GIAMBIAGI, Fabio; MOREIRA, Maurício Mesquita (Org.). A economia brasileira nos anos 90. Rio de Janeiro: BNDES, 1999.

NASSIF, Luiza; TEIXEIRA, Lucas; ROCHA, Frederico. Houve redução do impacto da indústria na economia brasileira no período 1996-2009? Uma análise das matrizes insumoproduto. Economia e Sociedade, Campinas, v. 24, n. 2, 2015.

OREIRO, José Luis; FEIJÓ, Carmem. Desindustrialização: conceituação, causas, efeitos e o caso brasileiro. Revista de Economia Política, São Paulo, v. 30, n. 2, abr./jun. 2010. 
SALM, Claudio; SABOIA, João; CARVALHO, Paulo Gonzaga M. Produtividade na indústria brasileira: questões metodológicas e novas evidências empíricas. Pesquisa e Planejamento Econômico, Rio de Janeiro, v. 27, n. 2, ago. 1997.

TAVARES, Maria da Conceição. Auge e declínio do processo de substituição de importações no Brasil. In: TAVARES, M. C. Da substituição de importações ao capitalismo financeiro. 7. ed. Rio de Janeiro: Zahar, 1978.

TORRES, Ricardo L.; CAVALIERI, Henrique. Uma crítica aos indicadores usuais de desindustrialização no Brasil. Revista de Economia Política, São Paulo, v. 35, n. 4, out./dez. 2015 .

VERÍSSIMO, Michele P.; XAVIER, Clésio L. Tipos de commodities, taxa de câmbio e crescimento econômico: evidências da maldição dos recursos naturais para o Brasil. Revista de Economia Contemporânea, Rio de Janeiro, v. 18, n. 2, maio/ago. 2014. 